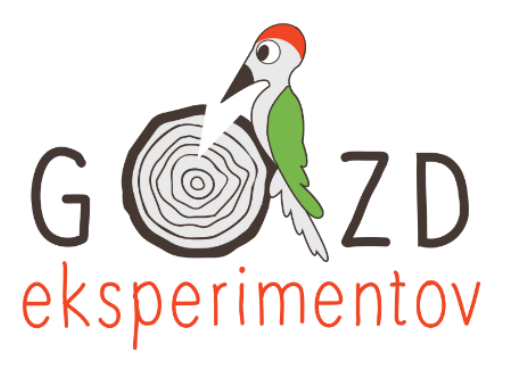

\title{
Nekaj zdravega, sladkega in užitnega iz gozda
}

JESENSKI IZOBRAŽEVALNI SEMINAR Z AKTIVNOSTMI GOZDNE PEDAGOGIKE

Povzetek referatov

Ljubljana, 3. oktober 2019 


\section{KOLOFON}

Založnik: Gozdarski inštitut Slovenije, založba Silva Slovenica, Ljubljana 2019

Zbirka: Gozd eksperimentov

Naslov: NEKAJ ZDRAVEGA, SLADKEGA IN UŽITNEGA IZ GOZDA - Jesenski izobraževalni seminar $z$ aktivnostmi gozdne pedagogike

Urednica: mag. Špela Planinšek

Tehnična urednika: Erika Kozamernik, Simon Zidar

Avtorji besedil: mag. Špela Planinšek, Erika Kozamernik, Simon Zidar, dr. Anže Japelj, Matic Konc in dr. Peter Železnik

Fotografije: avtorji so navedeni v dokumentu

Cena: brezplačno

Izdaja: elektronska izdaja (pdf)

Elektronski izvod: DOI 10.20315/SilvaSlovenica.0013

Kataložni zapis o publikaciji (CIP) pripravili v Narodni in univerzitetni knjižnici v Ljubljani COBISS.SI-ID=304047104

ISBN 978-961-6993-51-7 (pdf) 


\section{KAZALO VSEBINE}

KOLOFON

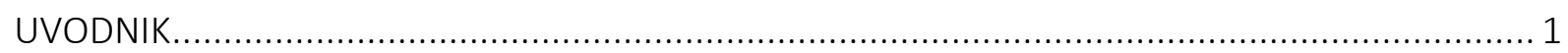

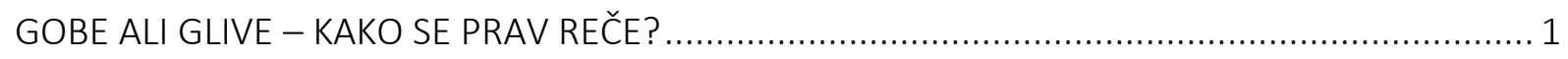

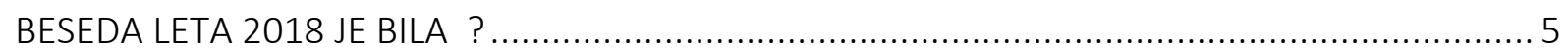

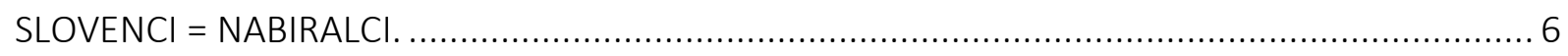

LEKARNA BREZ GOZDA NE OBSTAJA - BELA JELKA IN BELINAL.......................................... 8

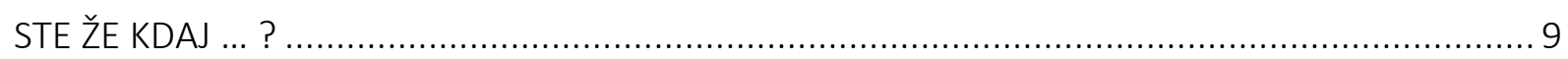

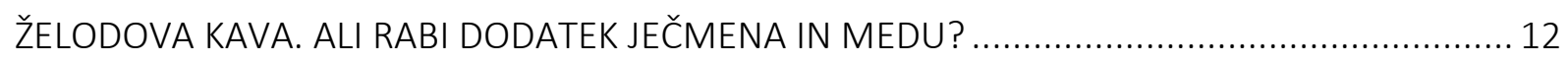

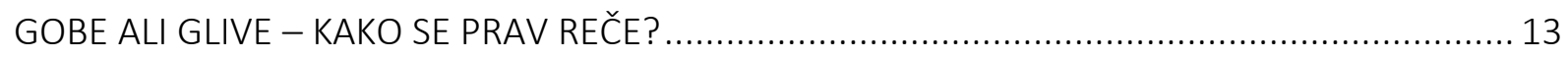

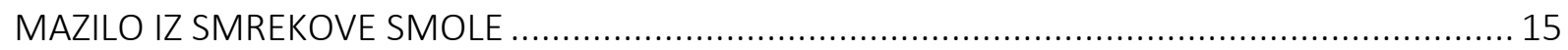

LEKARNA BREZ GOZDA NE OBSTAJA - BELA JELKA IN BELINAL.............................................. 17

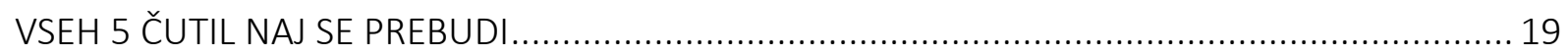

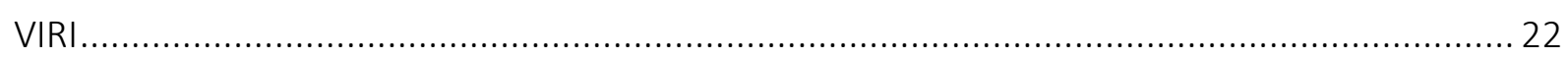




\section{UVODNIK}

mag. Špela Planinšek, Gozdarski inštitut Slovenije

Leto 2019 je za gozdarje, ki delamo na področju vzgoje in izobraževanja javnosti, minilo v sozvočju z Mednarodnim dnem gozdov. Vsako leto je izbrana ena glavna tema in tokrat je bila posvečena prikazu vloge gozda v procesu izobraževanja za trajnostni razvoj.

\section{Kako pa se je leto 2019 za slovenske gozdne pedagoge začelo?}

V celjskem mestnem gozdu, na velikem dogodku pod drevesno hišo!

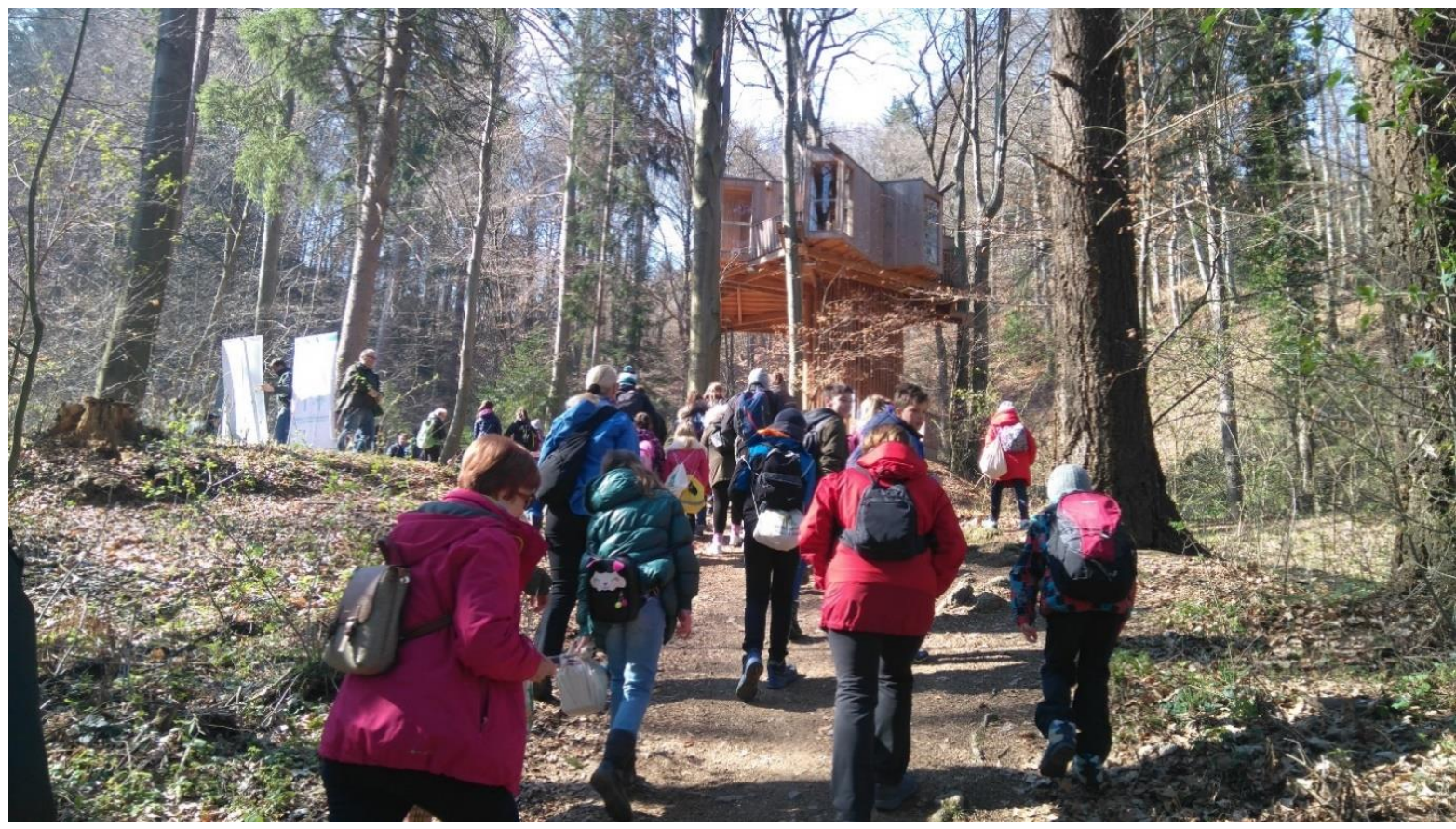

Slika 1: Mnogo ljudi je povabilo v gozd vzelo zares. In ni jim bilo žal. (foto: Š. Planinšek)

Zbrali smo se kolegi in soustvarjalci razvoja gozdne pedagogike, družbo pa so nam delali tudi naši financerji in uporabniki, pa tudi novinarji. Lahko rečemo, da je bil to odličen dan promocije gozdov in ozaveščanja o pomenu in nujnosti trajnostne rabe vseh vrst gozdov.

Leto 2019 mineva v duhu slogana mednarodnega dne gozdov »Gozdovi in učenje«. V Sloveniji smo slogan priredili v »Gozd je modrost" in pod to krilatico delovali celo pomlad, poletje in jesen.

Preko leta se je zvrstilo mnogo dogodkov na lokalnih ali regionalnih ravneh, ki so izobraževali različne ciljne skupine o gozdovih, trajnosti in gozdarstvu v Sloveniji. Največ dogodkov gozdarske organizacije običajno pripravijo $\mathbf{T}$ Tednu gozdov, ki je vedno zadnji teden maja. Več o njih najdete na spletnih straneh in socialnih omrežjih, saj vseh - kljub zelo dobrim tematikam - ne moremo opisati. 


\section{Jesenski izobraževalni seminar}

Aktivnosti Gozda eksperimentov v letu 2019 smo zaključili s seminarjem Nekaj zdravega, sladkega in užitnega iz gozda, ki se je zgodil hladnega 3. oktobra 2019.

V izobraževalnem seminarju z aktivnostmi gozdne pedagogike smo želeli združiti znanja, ki nekaterim že ustvarjajo delovna mesta, in potrebe širše javnosti, ki o teh nelesnih dobrinah ve precej, a kljub temu še ne dovolj, da bi se z njimi lahko poistovetila ali jih predajala kakovostno naprej.

V začetnem nagovoru seminarja je mag. Špela Planinšek strnila letošnje aktivnosti Gozdarskega inštituta Slovenije in Zavoda za gozdove Slovenije na področju vzgoje in izobraževanja ter gozdne pedagogike.

$\checkmark$ naslovu dogodka smo še napisali, da bodo udeleženci spoznali nekaj aktivnosti gozdne pedagogike, a kot smo bili opozorjeni na nedavnem kongresu gozdnih pedagogov v Latviji s strani latvijskih učiteljev brez dobre podlage ne gre! Brez predavanj naših domačih in vabljenih predavateljev torej ta seminar ne bi izpolnil osnovne zahteve - kvalitetnega predznanja.
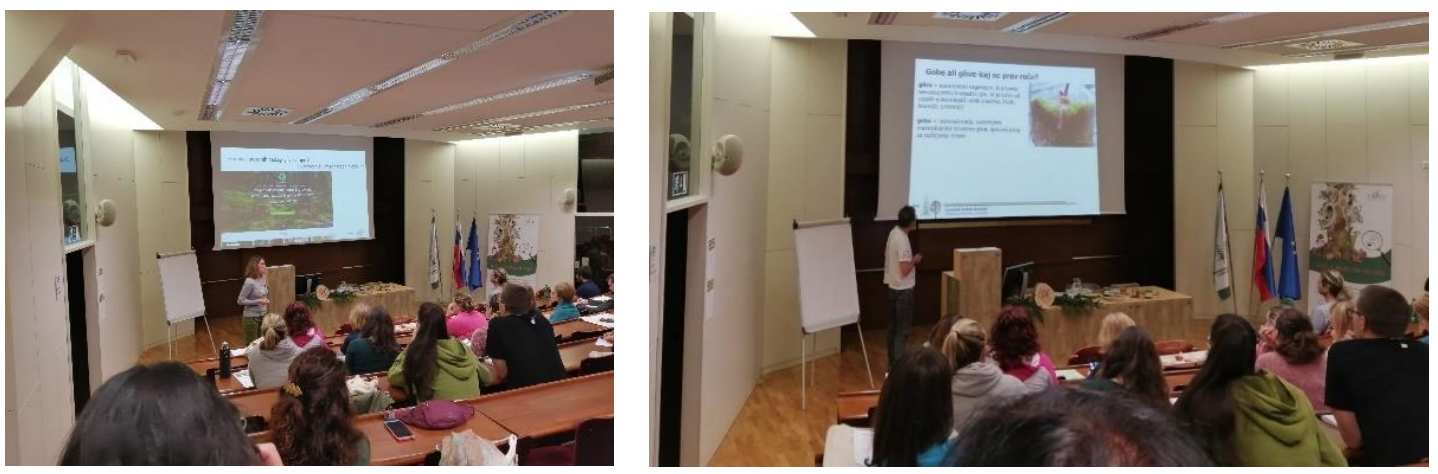

Slika 2: Predavanja strokovnjakov so bila prilagojena različnim ciljnim publikam. (foto: A. Alagić)

\section{Program predavanj:}

Slovenci = nabiralci - dr. Anže Japelj, mag. Špela Planinšek, Gozdarski inštitut Slovenije

- Gobe ali glive - kako se prav reče? - dr. Tine Grebenc, Gozdarski inštitut Slovenije

* Beseda leta 2018 je bila? - dr. Janez Prešern, Kmetijski inštitut Slovenije

- Lekarna brez gozda ne obstaja - dr. Samo Kreft, Fakulteta za farmacijo

\section{Predavanja so ponudila vrsto zanimivih dejstev:}

"Slovenci smo po odstotku nabiralcev ne-lesnih gozdnih dobrin na tretjem mestu v Evropi (za Čehi in Latvijci)." - dr. Anže Japelj

„KIjub temu, da SSKJ govori, da so glive rastline, to ni res - so svoje kraljestvo!« - dr. Tine Grebenc »Poznamo tudi divje živeče čebele in čmrlje.» - dr. Janez Prešern

»/zvleček lesa jelke ugodno vpliva na krvni sladkor in aterosklerozo." - dr. Samo Kreft

Dopoldanska predavanja so več kot 40 udeležencem nudila splošna, a znanstveno podprta dejstva o pestrem naboru nelesnih gozdnih dobrin, obširen popoldanski del pa nekaj terenskih predstavitev in aktivnosti gozdne pedagogike s strokovnimi podlagami na prostem. 


\section{Gozdna pedagogika na prostem}

Po uvodni ogrevalni vaji s pomenljivim naslovom "Ste že kdaj ... ?" smo se v popoldanskem delu jesenskega seminarja sladkali s kostanjevo rulado, žvečili smrekovo smolo in se mazali s finskim mazilom podjetja Smrekovit. Drago Lovrec iz Ekopražarne Lovro nam je skuhal želodovo kavo (ozaljšano z ječmenom in medom) in opisal, kako v sestojih hrasta doba (dobravah) pridobiva želod. Pri prof. Samu Kreftu pa smo eksperimentirali s kislinami in bazami. Ena od aktivnosti gozdne pedagogike je udeležence spodbujala, da bi na podlagi voha (ekstraktov) ločili drevesne vrste, a se je po mnenju dr. Petra Železnika to izkazalo za težko nalogo, saj naš nos ne loči tako podobnih vonjev.

\section{Program delavnic na prostem:}

Preizkusite svoj VOH

Gobe ali glive - kako se prav reče?

dr. Tine Grebenc, Gozdarski inštitut Slovenije

* Naredite kemijski EKSPERIMENT

Lekarna brez gozda ne obstaja - bela jelka in Belinal

dr. Samo Kreft, Fakulteta za farmacijo

\section{Kako iz semena dobimo OKUS?}

Želodova kava. Ali rabi dodatek ječmena in medu?

Drago Lovrec, Ekopražarna Lovro in Čebelarstvo Božnar

- Na smreko po ZDRAVJE

Mazilo iz smrekove smole

Matic Konc, Smrekovit

Naštejte svoje ČUTE

Vseh 5 čutil naj se prebudi

dr. Peter Železnik, Gozdarski inštitut Slovenije in Berryshka

Zadovoljni smo, da smo lahko predali toliko strokovnih znanj o nelesnih gozdnih dobrinah, vsekakor pa se bomo trudili, da bomo še povečali količino praktičnih delavnic oz. aktivnosti gozdne pedagogike, ki jih pri tako zanimivih temah ni nikoli zadosti.

\section{Če vas zanima še več o nelesnih dobrinah evropskih gozdov:}




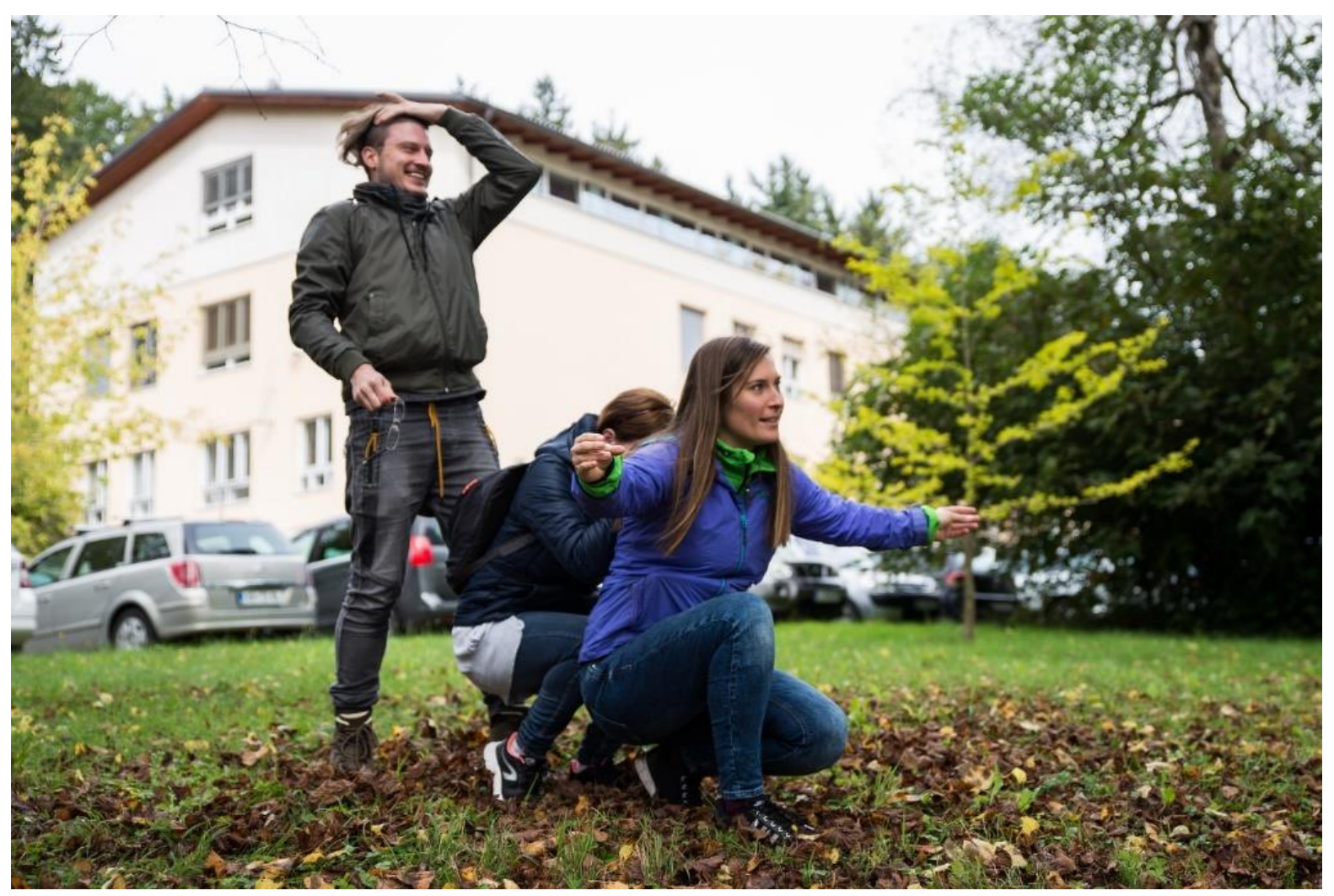

Slika 3: Pantomima gozdnih živali sodi med ogrevalne aktivnosti gozdne pedagogike in je vedno zanimiva. (foto: G. Skoberne)

\section{Kako pa naprej?}

V zadnjih letih gozdna pedagogika $v$ Sloveniji zopet vse bolj pridobiva na pomenu, kakovosti in ugledu. Tako ni več le domena gozdarjev, temveč se njene principe vse bolj uporablja tudi na drugih področjih. Prav tako v slovenskem prostoru ne manjka dobrih idej, ki hranijo mnoge potrebe javnosti po pristopih $\checkmark$ okoljski vzgoji. Vse več se poskušamo povezovati s pedagoškimi raziskavami in ustanovami, redno pa se udeležujemo mednarodnih srečanj gozdnih pedagogov Evrope. Ti nam prinašajo svež veter in nove aktivnosti, ki jih lahko posredujemo našim udeležencem seminarjev ali dogodkov. Vse naše aktivnosti pa pokažemo tudi njim in tako dobimo neposreden odziv strokovnjakov na tem področju. To nas žene naprej, dialog pa lahko opozori na možne izboljšave aktivnosti.

Gozd eksperimentov skozi principe gozdne pedagogike promovira gozdarsko znanost tako na domačih kot tujih tleh že od leta 2011. Številna spoznanja naših raziskovalcev pripomorejo k zakladnici znanja o gozdu in na uporaben način učijo, kako trajno ravnati z gozdom. Pri svojem delu uporabljamo načela Tekočega učenja $($. Vse aktivnosti gozdne pedagogike temeljijo na načelih Evropske strategije gozdne pedagogike, ki smo jo ustvarjali gozdni pedagogi v podskupini Gozdnih komunikatorjev leta 2017.

Več o nas najdete na https://www.gozd-eksperimentov.gozdis.si/.

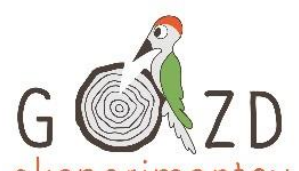

eksperimentov 


\section{Čemu povzetek referatov?}

Kot pomoč pri pripravi vaših nadaljnjih izobraževalnih aktivnosti na temo gozdnih nelesnih proizvodov v skladu z gozdno pedagogiko smo za vas pripravili povzetek referatov, ki so bili predstavljeni na jesenskem izobraževalnem seminarju - Nekaj zdravega, sladkega in užitnega iz gozda.

Na sledečih straneh vas $v$ prvem delu popeljemo preko povzetkov predavanj, nato pa predstavimo pregled aktivnosti gozdne pedagogike, ki smo jih izvedli v obliki delavnic.

Želimo si, da bi bilo pripravljeno gradivo v dobrodošlo pomoč pri vašem delu.

Veliko užitkov pri aktivnostih v gozdu!
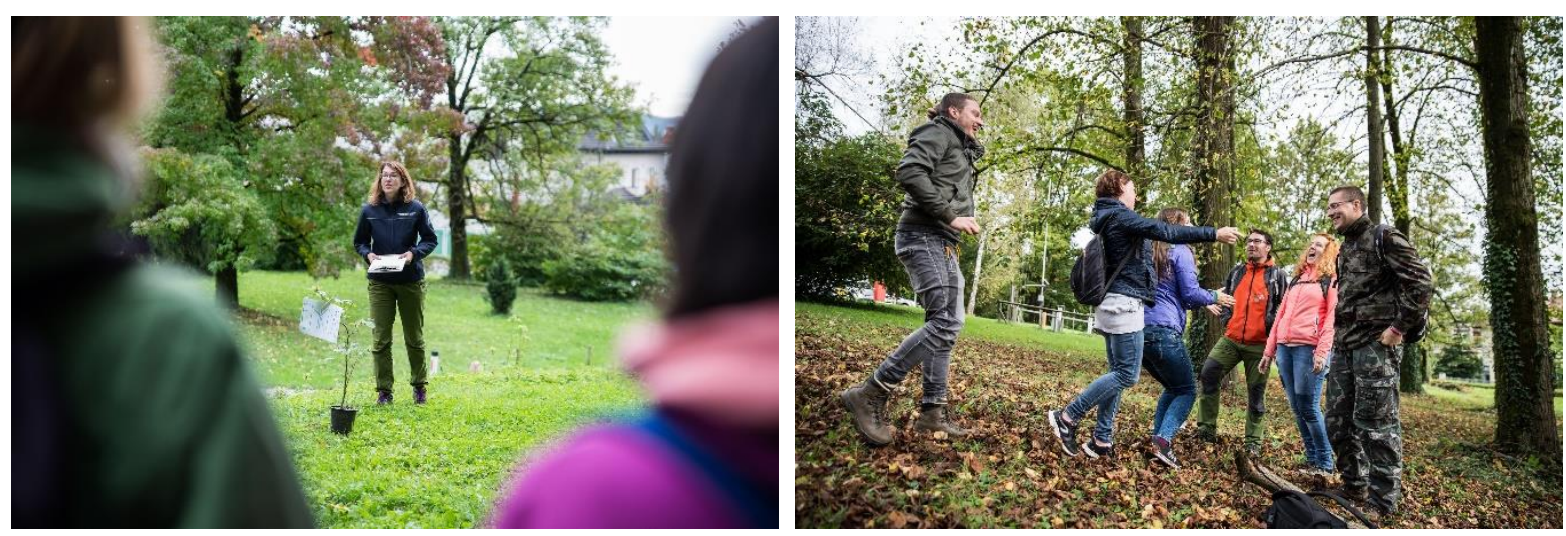

Slika 4: Gozdna pedagogika na prostem je odličen način približevanja pomena gozda različnim publikam. (foto: G. skoberne).

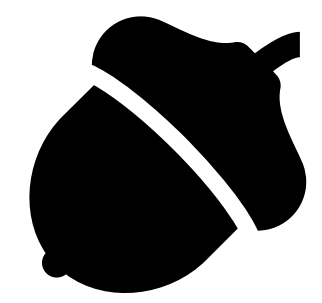

\section{Pri organizaciji seminarja so sodelovali:}

Špela Planinšek, Erika Kozamernik, Ajša Alagić, Peter Železnik, Kristina Sever in Simon Zidar.

Strokovna predavanja so izvedli: dr. Anže Japelj, dr. Tine Grebenc, dr. Samo Kreft in dr. Janez Prešern.

Izvedbo seminarja so podprli Smrekovit, Ekopražarna Lovro, Čebelarstvo Božnar, Čebelarska zveza Slovenije, Berryshka, Gozdarski inštitut Slovenije ter Zavod za gozdove Slovenije, ki se jim najlepše zahvaljujemo.

Posebna zahvala gre avtorju nazornih in estetskih fotografij, Gregorju Skobernetu. 


\section{GOBE ALI GLIVE - KAKO SE PRAV REČE?}

dr. Tine Grebenc, Gozdarski inštitut Slovenije

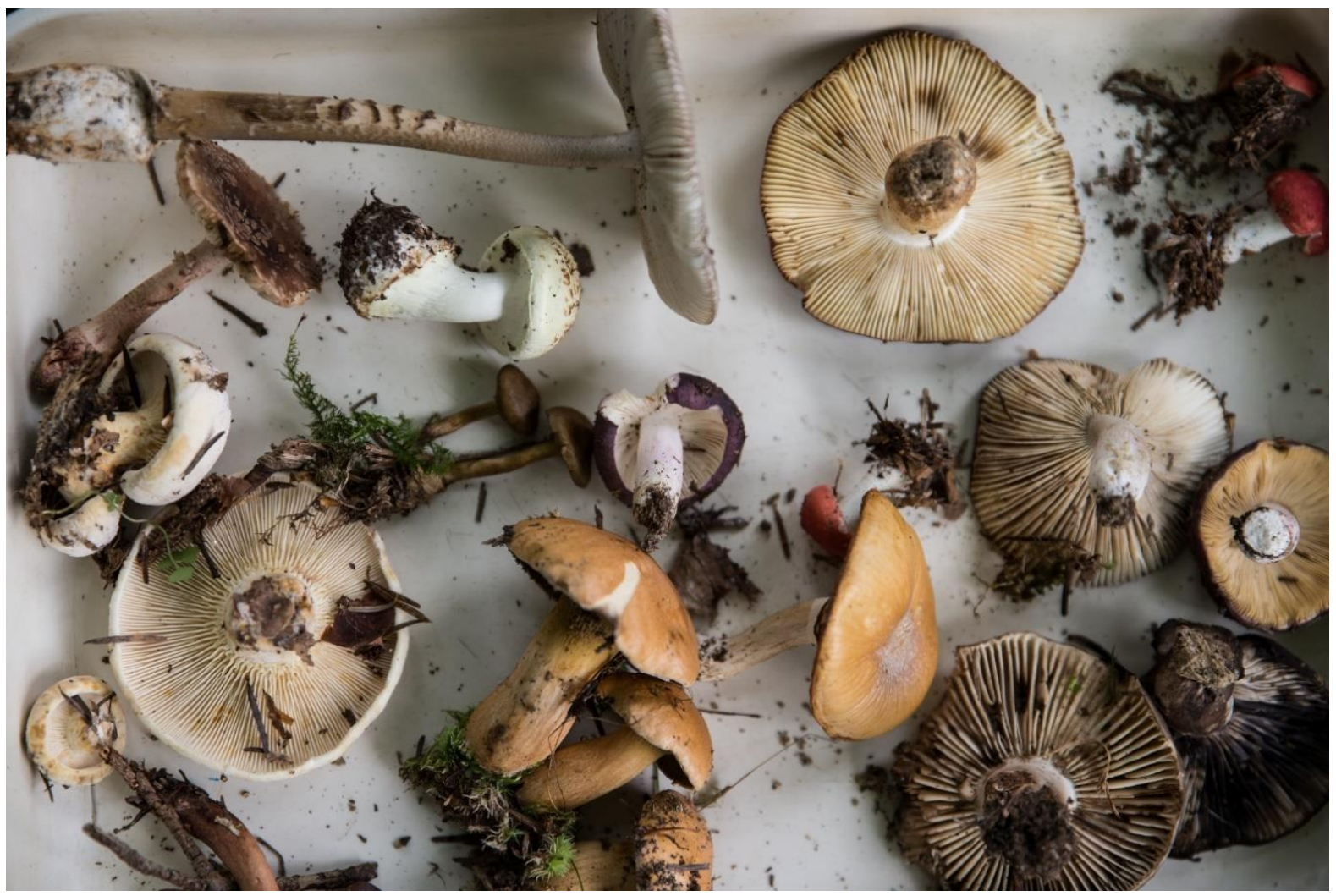

Slika 5: Pestrost gliv. No, na sliki so le gobe - nadzemni razmnoževalni deli gliv. (foto: G. Skoberne)

\section{Razlaga pojmov}

Glede na Slovar slovenskega knjižnega jezika imata zgornja pojma naslednji pomen:

glíva -e ž (í) = nav. mn., bot. rastline, ki so brez klorofila in živijo kot gniloživke ali zajedavke, Mycophyta: glive se uvrščajo med nižje rastline / gliva zajedavka

biol. gliva cepljivka bakterija; gliva kvasovka)

góba -e ž (ọ́) = rastlina brez listnega zelenila, navadno s klobukom in betom: nabirati gobe; zastrupiti se z gobami; hiše so rastle kakor gobe po dežju / strupene, užitne gobe / dušene gobe; gobe v smetani

Zgornje definicije so napačne, saj so glive organizmi, ki pripadajo samostojnemu kraljestvu, torej niso rastline in prav tako jih ne gre mešati z bakterijami.

Gliva je evkariontski organizem, ki pripada samostojnemu kraljestvu gliv, in je ločen od ostalih evkariontskih oblik (rastline, živali, kromisti, protozoji) ter ima svoje značilnosti. 
Izraza goba ne smemo enačiti z glivo. Goba označuje makroskopsko (vidno) strukturo glive, ki je specializirana za razširjanje trosov in je namenjena razmnoževanju glive.

Poleg pojmov gliva in goba imamo tudi izraz micelij oziroma glivno nitje (tudi t.i. hife). Hife so vegetativni, pogosto nam neviden del glive, ki se razrašča $\vee$ okolici in je lahko celo večji od nadzemnega razmnoževalnega dela (gobe). Izraz podgobje pa označuje vegetativni del glive, vključno z mikorizo in drugače specializiranimi hifami (apresoriji, cistide, ...).

Gobani so svoj rod gliv (Boletus sp.), v katerega spadajo tudi užitne vrste gobanov - vsem poznani jurčki. Poznan je tudi izraz gobice, ki označuje rod gliv s psihoaktivnimi substancami (npr. psilocibinom).

\section{Kje jih najdemo?}

Glive lahko najdemo povsod okoli nas: v pomivalnih strojih, na koži, v prebavilih, v kopalnici, $v$ tleh, $v$ pivu, v medu, omogočajo koristno mikorizo z rastlinami, ...
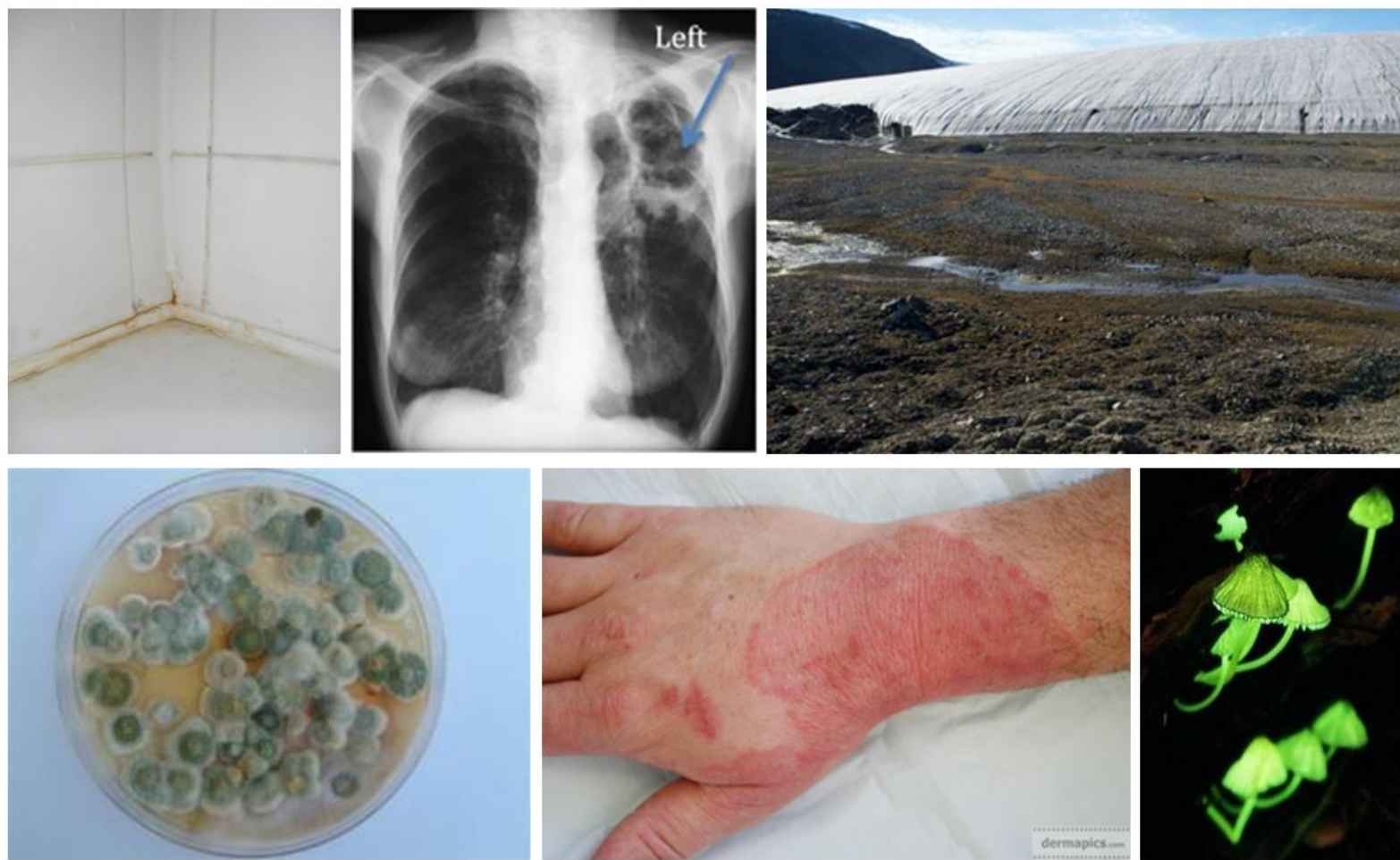

Slika 6: Glive lahko najdemo praktično povsod. (povzeto iz predstavitve Grebenc T. 2019: Gobe ali glive - kako se prav reče?).

\section{Podzemne glive}

Podzemne glive so morfološko precej pestre in raznolike. Nekatere izmed njih se uporablja tudi $\vee$ kulinarične namene - to so vsem dobro poznani tartufi oz. gomoljike (različne vrste). 
Med komercialno (kulinarično) zanimivimi vrstami so npr. bela gomoljika, poletna gomoljika, Perigordska gomoljika in kitajska gomoljika.

Gomoljike se iščejo s pomočjo svinj, psov ali s sledenjem drugim (divjim) živalim.
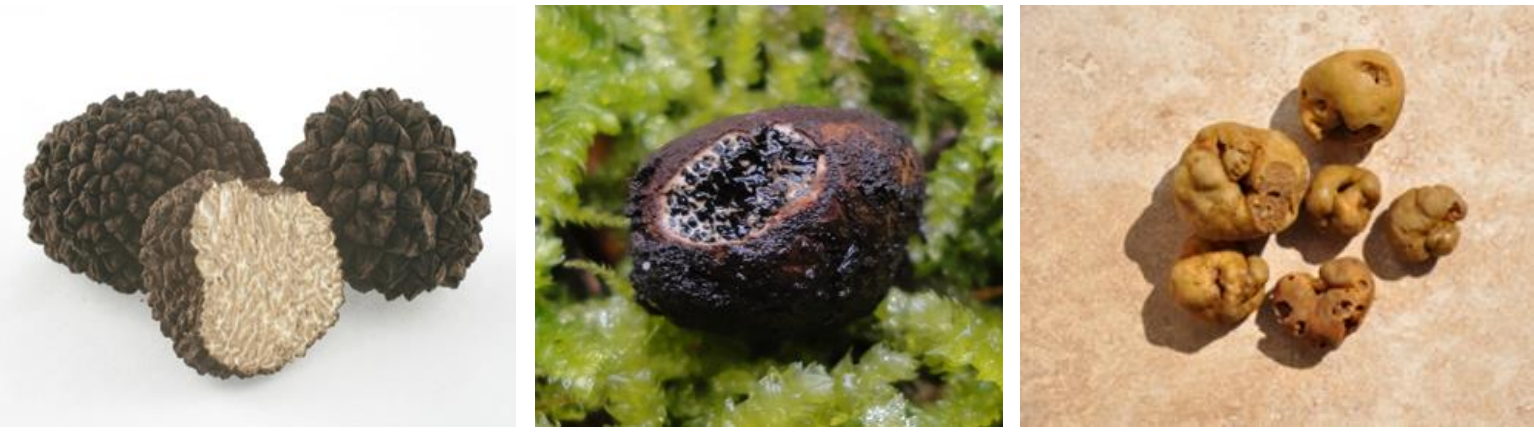

Slika 8: Poletna gomoljika (Tuber aestivum) - komercialna vrsta; Melanogaster sp. - druge podzemne glive (neprave gomoljike), ki se jih ne uporablja v kulinarične namene; Tuber excavatum - prava gomoljika, ki se je ne uporablja v prehrani (povzeto iz predstavitve Grebenc T. 2019: Gobe ali glive - kako se prav reče?).

\section{Biologija gomoljik}

Gomoljke se naravno pojavljajo le na severni polobli. Njihove trose razširjajo živali. Vse vrste živijo v sožitju (mikorizi) z drevesnimi partnerji. Nekatere vrste so zelo drage za nakup.

\section{Življenjski krog gomoljik:}

1=trosi, 2= kaleči trosi, 3= vzpostavitev simbioze (mikorize), 4 = spolno razmnoževanje med raznospolnimi hifami; 5 = „oplojene“ celice in tvorba zametka gomolja; 6 = gomolj (tartuf) z zrelimi trosi

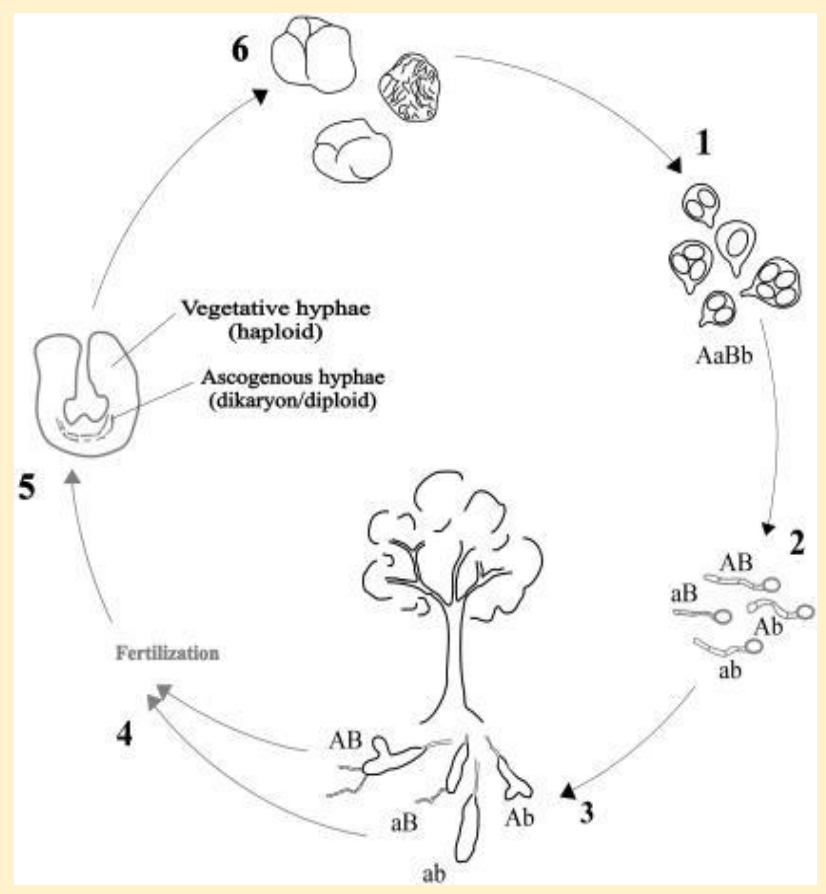

Slika 7: Življenjski krog gomoljik. 
Za gomoljike je značilna velika vrstna pestrost, z veliko stopnjo regionalnih in kontinentalnih endemitov. $\checkmark$ nekaterih študijah so zabeležili 124 vrst oz. taksonov gomoljik na svetu.

Raziskava genetske pestrosti izbranih vrst gomoljik je pokazala, da je razširjenost sorodnih genotipov (genetskih zapisov) gomoljik povezana s poledenodobnimi migracijami skupaj z drevesnim partnerjem, $\mathrm{s}$ katerim je posamezna vrsta $\vee$ sožitju. Na njihovo razširjenost pa je $\vee$ zadnjih desetletjih vplival tudi človek.

Gomoljike pa niso zanimive zgolj po videzu, ampak imajo tudi izrazito aromo. Ta je posledica lahkohlapnih organskih molekul, ki se med vrstami razlikujejo. Vsaka vrsta pa jih tvori več deset, lahko tudi do 70 hkrati, in vse skupaj dajo "aromo" posamezni vrsti tartufa. 


\section{BESEDA LETA 2018 JE BILA ?}

dr. Janez Prešern, Kmetijski inštitut Slovenije

... ČEBELA. Za besedo leta 2018 je bila izbrana beseda ČEBELA, kar je zagotovo povezano s tem, da smo prav na pobudo Slovenske čebelarske zveze dobili Svetovni dan čebel, ki ga praznujemo 20. maja.

Eden izmed pomembnih nelesnih gozdnih proizvodov je tudi med. Ves slovenski med je vsaj v določeni meri vezan na gozdne drevesne vrste.

Gozdni med je mešan med različnih vrst medu.

Za akacijev, lipov in kostanjev med čebele naberejo osnovo na cvetju - pijejo nektar iz nektarijev v cvetu, zato nastane nektarijev med. Med ima delež vode pod $20 \%$, saj bi v nasprotnem primeru prišlo do fermentacije.

Druga vrsta gozdnega medu je manin med, kar pomeni, da je tak med nastal iz mane, ki jo sproščajo kaparji in listne uši (npr. smrekov kapar in hojina uš). Ti pijejo floemski sok rastline, žival pa presežek sladkorja izloči. Ta se v obliki kapljice sprosti na veje, listje. To mano nato posrkajo čebele in to je osnova za med.

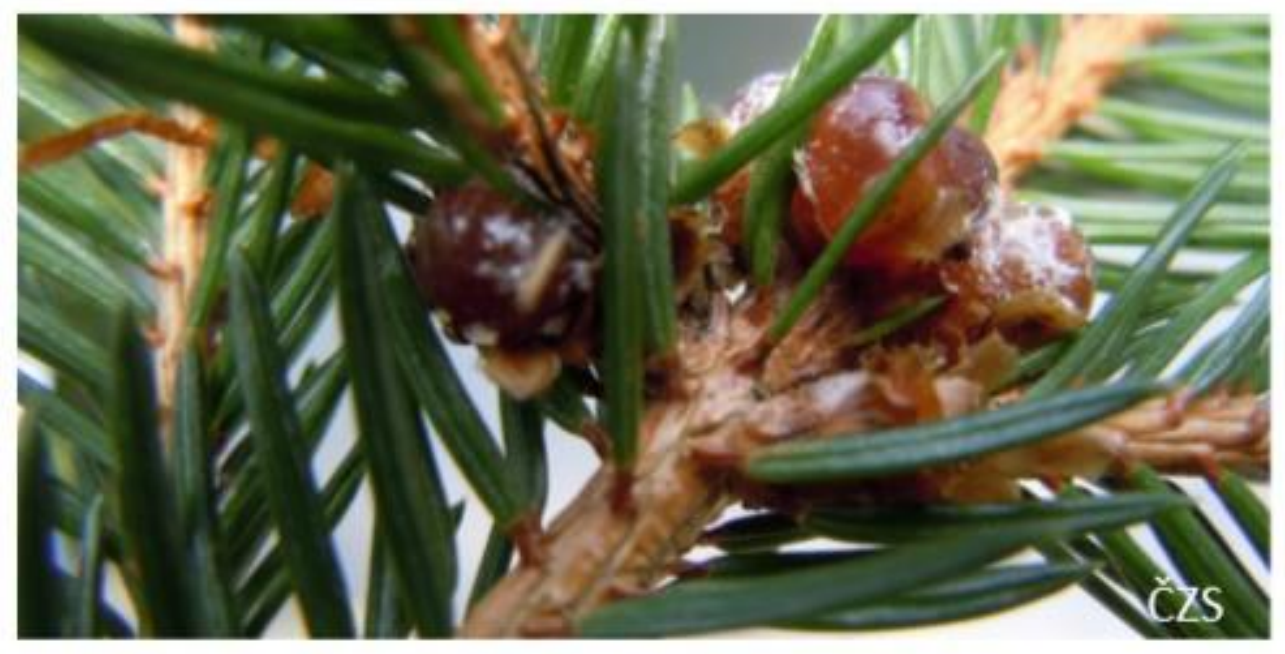

Čebelar lastniku zemljišča plača ali se drugače dogovori, da lahko k njemu na pašo pripelje svoje čebele.

Čebele nudijo tudi ekosistemske storitve: oprašujejo in so vektorji rastlinskih patogenov (npr. trosov različnih vrst rj).

Poznamo medonosne čebele in divje čebele, kamor sodijo čmrlji in čebele samotarke.Gozd s svojimi pestrimi oblikami debel in koreničnikov čebelam nudi tudi prostore za izdelavo gnezda oz. panja.

* Če najdeš čebeljo družino $v$ gozdu, sporoči to raziskovalcu Janezu Prešernu (janez.presern@kis.si).

Vaš podatek bo vnešen v informacijski portal COLOSS, ki vsebuje in išče informacije o čebeljih družinah, ki preživijo brez človeka. 


\section{SLOVENCI = NABIRALCI.}

dr. Anže Japelj in mag. Špela Planinšek, Gozdarski inštitut Slovenije

V letu 2016 je bilo v okviru projekta StarTree opravljeno anketiranje na temo porabe, nabiranja in trgovanja z nelesnimi gozdnimi proizvodi, v katero je bilo vključenih 28 držav EU, Srbija, Turčija in evropski del Rusije. Vzorec je zajemal 14864 gospodinjstev, izmed katerih jih je bilo 433 iz Slovenije.

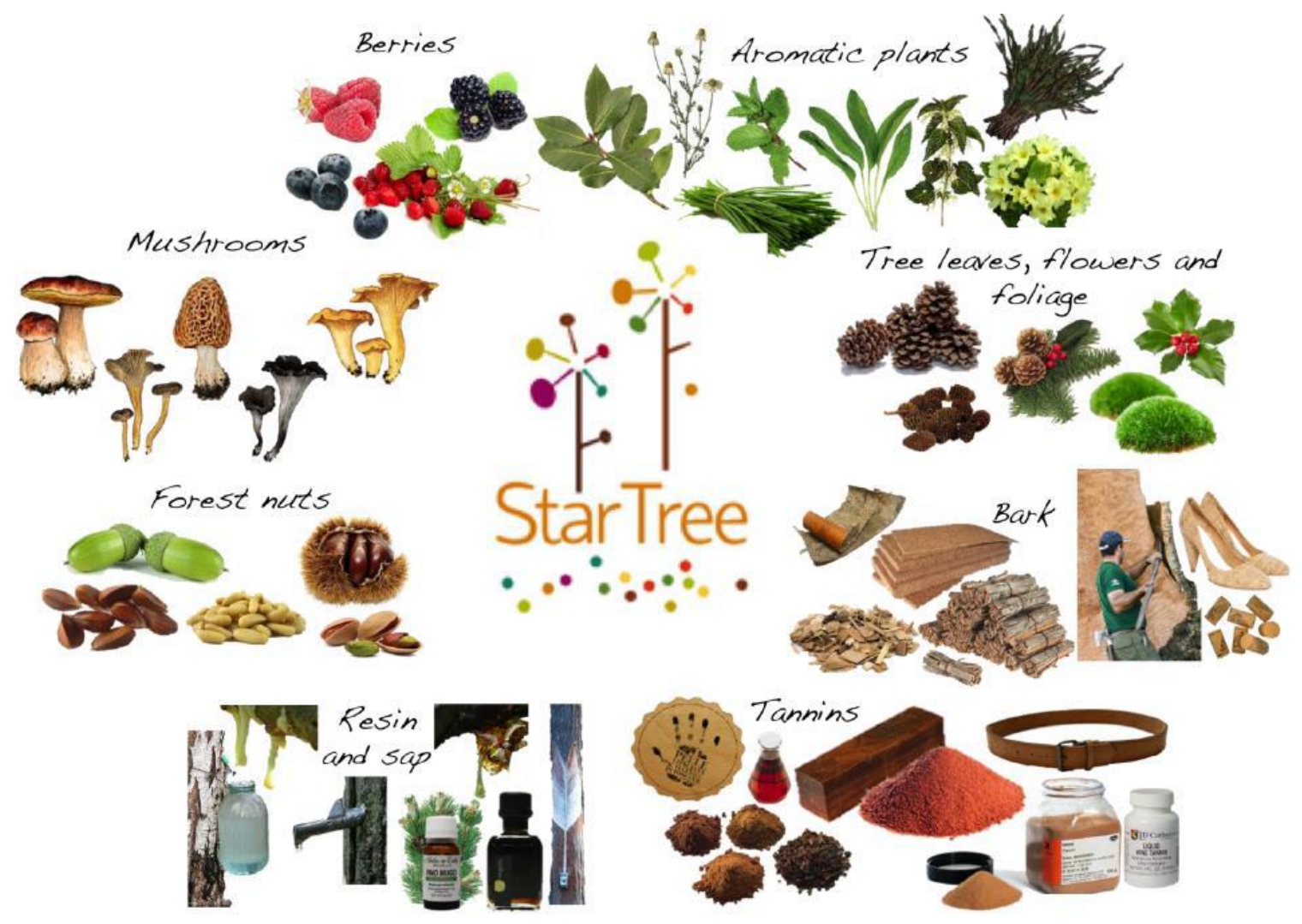

Slika 9: Nelesni gozdni proizvodi: jagodičevje, zdravilne in aromatske rastline, okrasno zelenje (listje, cvetovi in veje), lubje, tanini, drevesne smole in sok, oreščki in gobe. (vir: projekt StarTree)

\section{NELESNI GOZDNI PROIZVODI V SLOVENIJI - nekaj dejstev}

Običajno se člani gospodinjstva 3 krat na leto odpravijo $\mathbf{v}$ gozd in nabirajo NLGP.

To največkrat naredijo $v$ paru.

Več kot tri četrtine vprašanih za prepoznavanje vrst NLGP ni opravilo nobene oblike izobraževanja.

Za skoraj 4/5 gospodinjstev je nabiranje le prostočasna dejavnost in te dejavnosti ne opravljajo tržno.

Med največji oviri pri nabiralništvu uvrščajo slabo vreme in zakonske omejitve nabranih količin. 
Projekt je obravnaval problematiko nelesnih gozdnih proizvodov (NLGP) z vidikov krepitve ekološke proizvodne sposobnosti (predvsem v smislu gojenja gozdov), analize trgovine z NLGP ter razčlenjevanja vrednostne verige (proizvodnja-pridobivanje-predelava-trženje) in uresničevanja inovativnih pristopov uresničevanja poslovnih modelov ter političnih programov in orodij.

Z anketiranjem gospodinjstev smo ugotavljali, koliko NLGP povprečno Slovenci užijejo v letu in kolikšen je obseg nabiranja NLGP v naravi ter kolikšna je poraba NLGP gospodinjstev.

Ugotovili smo, da med 14 kategorijami NLGP slovenska gospodinjstva:

* najpogosteje uživajo sveže in sušene oreške in jagodičevje, slednje (predvsem borovnice, jagode in maline) v naravi tudi največkrat nabirajo;

- precej pogosto nabirajo še zdravilne in aromatske rastline (najpogosteje regrat in cvetove bezga), gozdne oreške (predvsem kostanj) ter gobe (največkrat jurčke in lisičke);

- 1/4 nabira tudi okrasno zelenje (najpogosteje cvetje in storže, sledi tudi mah in listje);

- le nekaj gospodinjstev $(0,2 \%)$ pa je nabiralo splošno precej prezrte NLGP - tartufe. Spodaj so podani deleži gospodinjstev, $v$ katerih jih je vsaj en član vsaj enkrat nabiral:

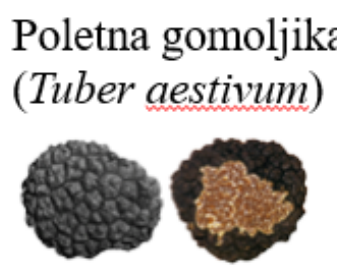

$0 \%$
Črni tartuf

(Tuber melanosporum)

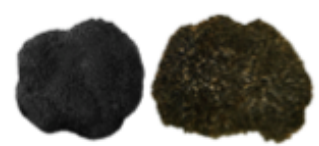

$0,2 \%$
Zimska gomoljika

(Tuber brumale)

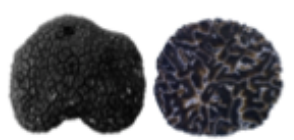

$0 \%$
Grbičasta gomoljika

(Tuber borchii)

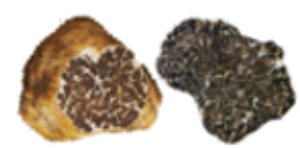

$0 \%$
Bela gomoljika

(Tuber magnatum)

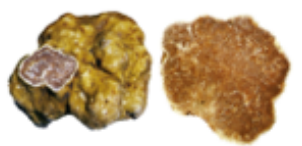

$0 \%$ 


\section{LEKARNA BREZ GOZDA NE OBSTAJA}

dr. Samo Kreft, Fakulteta za farmacijo

$\checkmark$ gozdu najdemo veliko rastlin z zdravilnimi učinki. Pri smreki, jelki in boru se $v$ zdravilne namene uporablja smolo, vršičke in eterično olje. Pri češnji, čremsi, črnem trnu, glogu, borovnici, brusnici se na primer uporablja plodove. Spet pri tretjih pa se zdravilni učinki skrivajo v lubju, cvetovih ali listih oziroma iglicah.

Ena izmed drevesnih vrst z zdravilnimi učinki je tudi bela jelka (Abies alba). Iz njenega lesa se pridobiva izvleček, katerega koristne lastnosti so prepoznavali že v preteklosti (npr. časopisni članek iz leta 1939).

Izvleček lesa bele jelke ima zelo visoko vsebnost antioksidantov. Dokazana je bila tudi velika in vitro antioksidativna aktivnost izvlečka lesa bele jelke $v$ primerjavi $z$ resveratrolom, vitaminom $E$ in polifenolom zelenega čaja (Tavčar Benković et al. 2017). Zaradi dokazanih zdravilnih učinkovitosti je bil izvleček lesa bele jelke oblikovan v produkt Belinal.
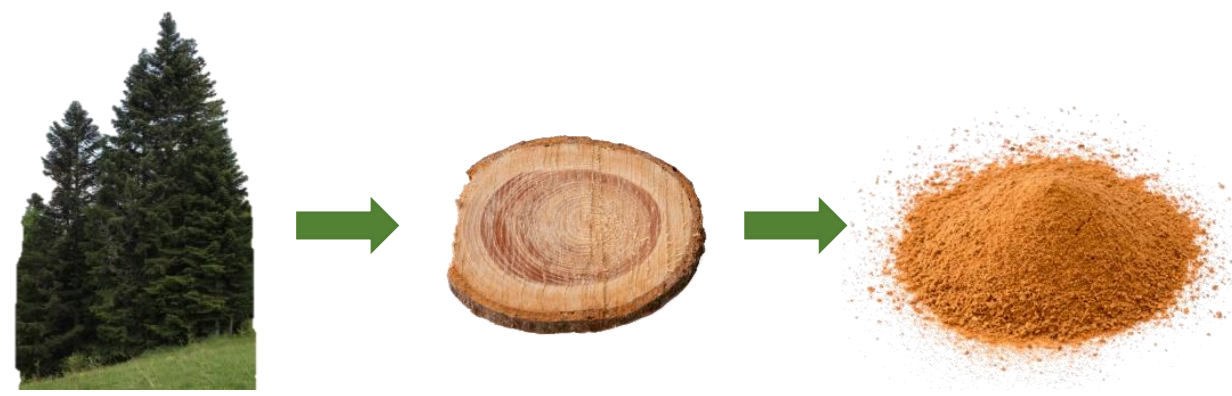

Slika 10: Zdravilni učinek ima izvleček iz lesa bele jelke (Abies alba). (povzeto iz predstavitve Kreft S. 2019: Lekarna brez gozda ne obstaja)

Ugotovljeno je bilo tudi, da Belinal učinkovito uravnava raven sladkorja v krvi (Debeljak et al. 2016), ščiti žile pred aterosklerozo (nastankom in rastjo oblog v arterijah) (Drevenšek et al. 2015) in ščiti srce pred posledicami kapi (Drevenšek et al. 2016). Zanimive so tudi raziskave in rezultati vpliva uporabe kreme z ekstraktom bele jelke na izboljšanje kožne funkcije in izgleda (Tavčar 2016).

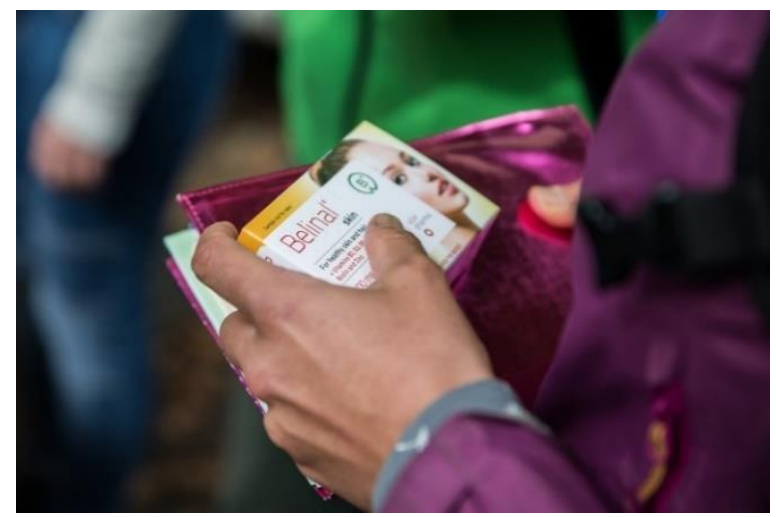

Slika 11: Izvleček lesa bele jelke je za primernejšo uporabo oblikovan v izdelek Belinal. (foto: G. Skoberne) 


\section{Ogrevalna vaja in razdelitev $v$ skupine} STE ŽE KDAJ ... ?

mag. Špela Planinšek, Gozdarski inštitut Slovenije

\section{Starost}

2.-3. triada OŠ, SŠ, odrasli

Učni cilj, ki ga dosežemo z aktivnostjo

Udeleženec se zaveda, da je človek odgovoren za trajnostni razvoj.

Udeleženec zna sestaviti preproste prehranjevalnih verige in jih povezati v prehranjevalne splete.

\section{Trajanje}

$10-20 \mathrm{~min}$

\section{Št. Oseb}

$12-20$

\section{Kaj bodo udeleženci spoznali?}

Gozdovi nam nudijo različne storitve. Nekatere so materialne (gozdni sadeži, gobe, les...), druge nematerialne (dvig razpoloženja, pestrost podob, čisto okolje...). Gozdarji jih trenutno delimo na tri večje skupine: proizvodne (les, gozdni sadeži...), ekološke (čist zrak in voda,...) ter socialne (rekreacija, izobraževanje...). Vse pogosteje pa opozarjamo tudi na manj opazne storitve gozdov (opraševanje, filtracija onesnaženega zraka, ohranjanje rastlinske in živalske pestrosti...).

Poskusili se bomo spomniti povsem običajnih in nekaterih nenavadnih produktov, ki jih lahko nudi gozd.

Nekatere gozdne materiale so naši starši ali stari starši uporabljali še nedavno nazaj, nekatere spet obujamo v življenje, drugi so stalnica pri obisku gozda. Kakšna je naša navezanost na izdelke iz gozda in kako pogosto jih rabimo, bo pokazala ta aktivnost.

\section{Kaj potrebujemo?}

4 trše papirje A4 ali A3, debel flomaster, lepilni trak ali žebljiček, fotografije različnih gozdnih živali

\section{Izvedba}

Izberemo precej raven prostor, saj bomo med aktivnostjo prehajali med 4 določenimi točkami. Pred aktivnostjo napišemo 4 liste: nikoli, občasno, pogosto, vedno. Liste razporedimo čim širše po prostoru (jasi, travniku), naj bodo vidni od daleč.

Pripravimo si nekaj fotografij gozdnih živali. Bodite kreativni, izberite ptice, plazilce, velike in male živali. 
Da se skupina nekoliko bolje spozna, jim (glasno, da nas slišijo!) zastavimo nekaj vprašanj (predlogi):

- Ste se že kdaj zastrupili z gobami?

- Ste že kdaj jedli/pili užiten produkt iz želoda?

- Ste kdaj žvečili smrekovo smolo?

- Vas vonj gozdnih jagod popelje nazaj v otroštvo?

- Ste se kdaj spraševali, zakaj imajo drevesa smolo?

- Ali kdaj, ko zbolite, uporabite zdravila iz narave?

- Ste pozorni na izvor medu, ki ga kupujete?

- Ste že kdaj naredili kosilo izključno z dobrinami, vzetimi le iz narave?

- Ste že imeli prometno nesrečo z divjadjo?

Po prebranem vprašanju naj se skupina $v 1$ minuti razporedi na eno od 4 točk, ki je odgovor na vprašanje. Aktivnost spremenimo v gibalno in še bolj zabavno tako, da ob vprašanju pokažemo fotografijo živali, katere gibanje moramo oponašati, medtem ko prehajamo iz sedanje točke na naslednjo.

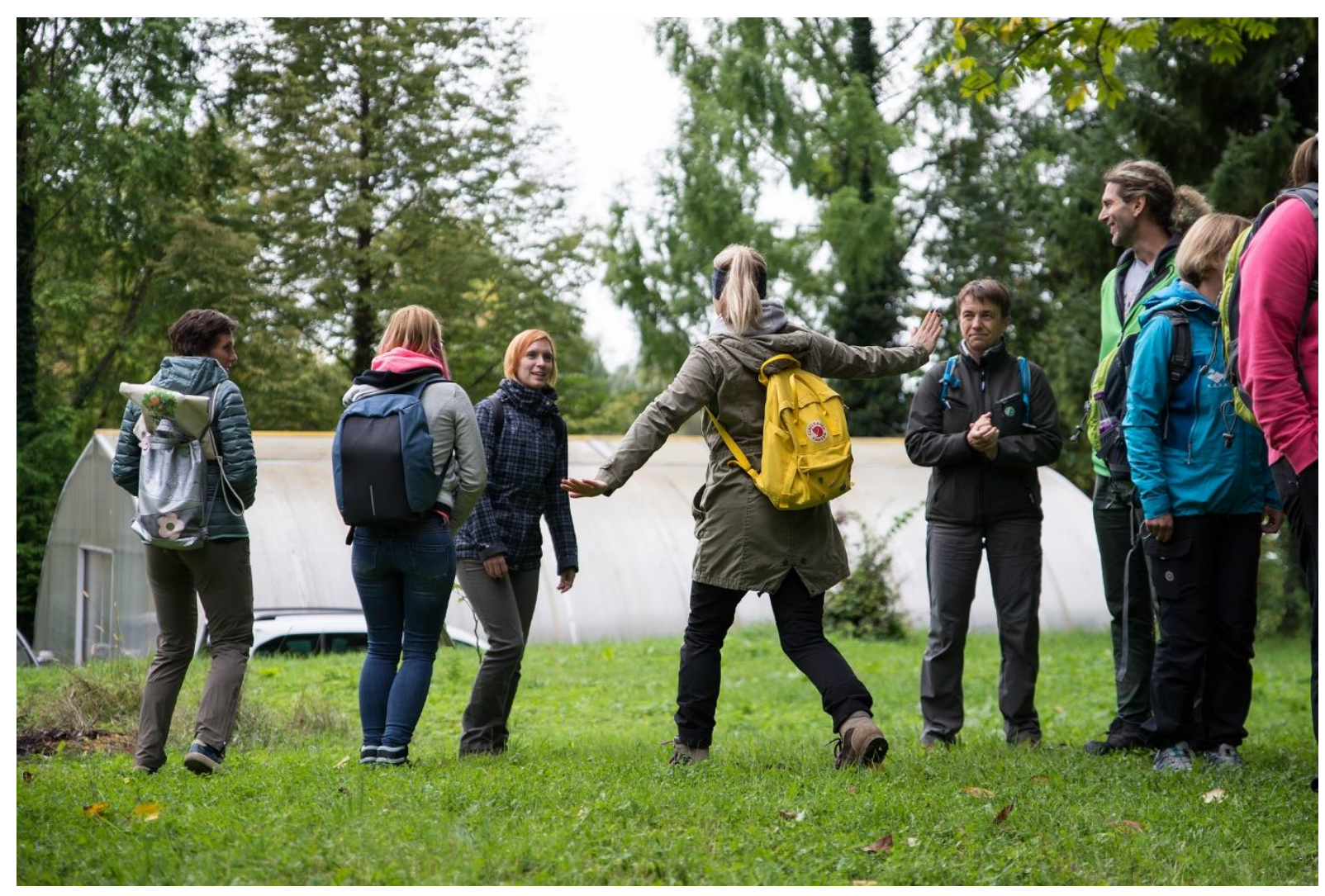

Slika 12: Prehod med točkama v stilu gozdne ptice. (foto: G. Skoberne) 

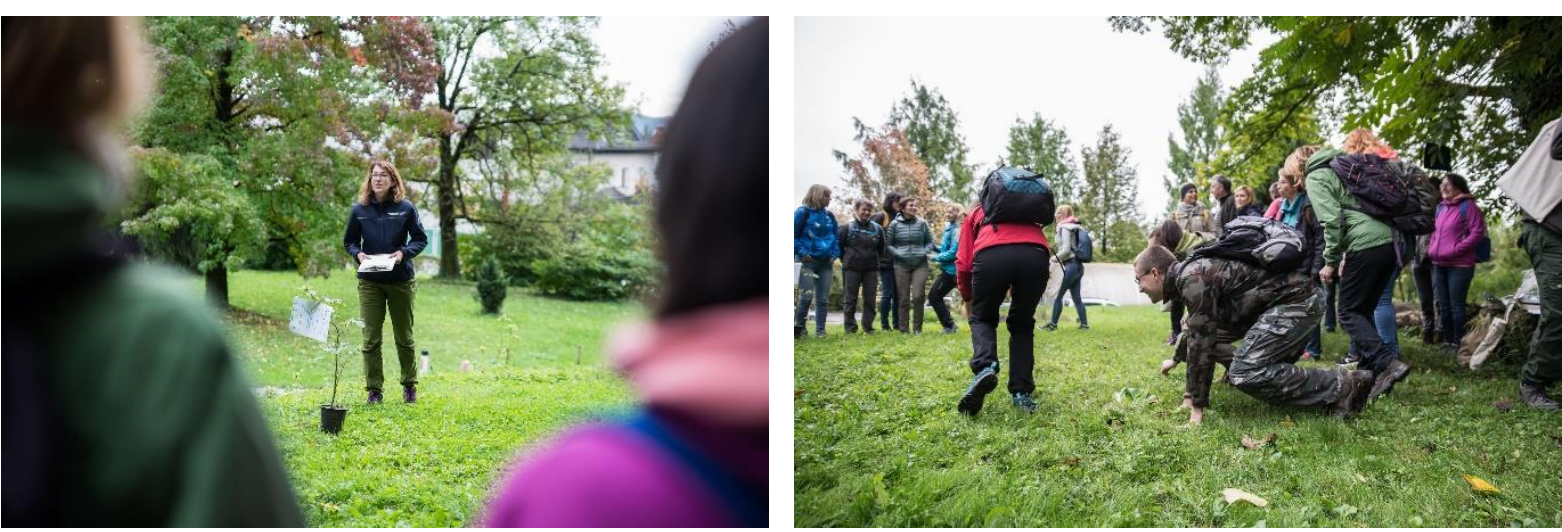

Slika 13: Postavljanje vprašanj naj bo glasno in jasno, udeležencem pa dajte možnost, da izvedejo prehod tako kot si zamislijo (počasi, domišljeno...) (foto: G. Skoberne)

Pri določenih vprašanjih spodbudite udeležence, naj povedo kakšno svojo izkušnjo s tem.

Delitev v skupine izvedemo z žrebanjem različnih vrst gozdnih plodov iz vrečke. Vanjo skrijemo po 1/3 storžev bora, smreke in duglazije (po želji spreminjamo).

Da pa delitev združimo še s pridobivanjem znanja, nadaljujemo s podatkom, da so vsi, ki so izžrebali smrekov storž, postali črtasti medvedki, smrekovi storži so postali gozdni postavneži in duglazijini storži bukovi kozlički. Udeleženci se sprašujejo, kaj neki pomenijo ta zanimiva imena...

Za še bolj izobraževalno delitev v skupine morajo najti ustrezne fotografije teh 3 živali. Te držijo v rokah 3 osebe/vodje skupin, ki bodo skupinam pomagale $v$ nadaljevanju dneva. Vodje skupin udeležencem povejo nekaj osnovnih informacij o izbranih treh živalih, ki imajo tako nenavadno ime.

Praktični del seminarja se zdaj lahko začne! 


\section{Kako iz semena dobimo OKUS?}

\section{ŽELODOVA KAVA. ALI RABI DODATEK JEČMENA IN MEDU?}

\section{Drago Lovrec, Ekopražarna Lovro}

Želodovo kavo so nekdaj uporabljali v ljudskem zdravilstvu predvsem za krepitev telesa, proti rahitisu. Zavretek učinkuje razkuževalno, krči tkivo, ustavlja notranje krvavitve in zapira. Lahko ga uporabljamo tudi zunanje, pri glivičnih kožnih boleznih, vnetjih kože in za grgranje pri vnetjih ustne votline in žrela. Znižuje krvni sladkor, deluje preventivno proti boreliji in uravnava delovanje ščitnice.

Želodova kava je obogatena s praženim ječmenom, ki zmanjšuje količino holesterola v krvi, bogat pa je z vitaminoma B in E.

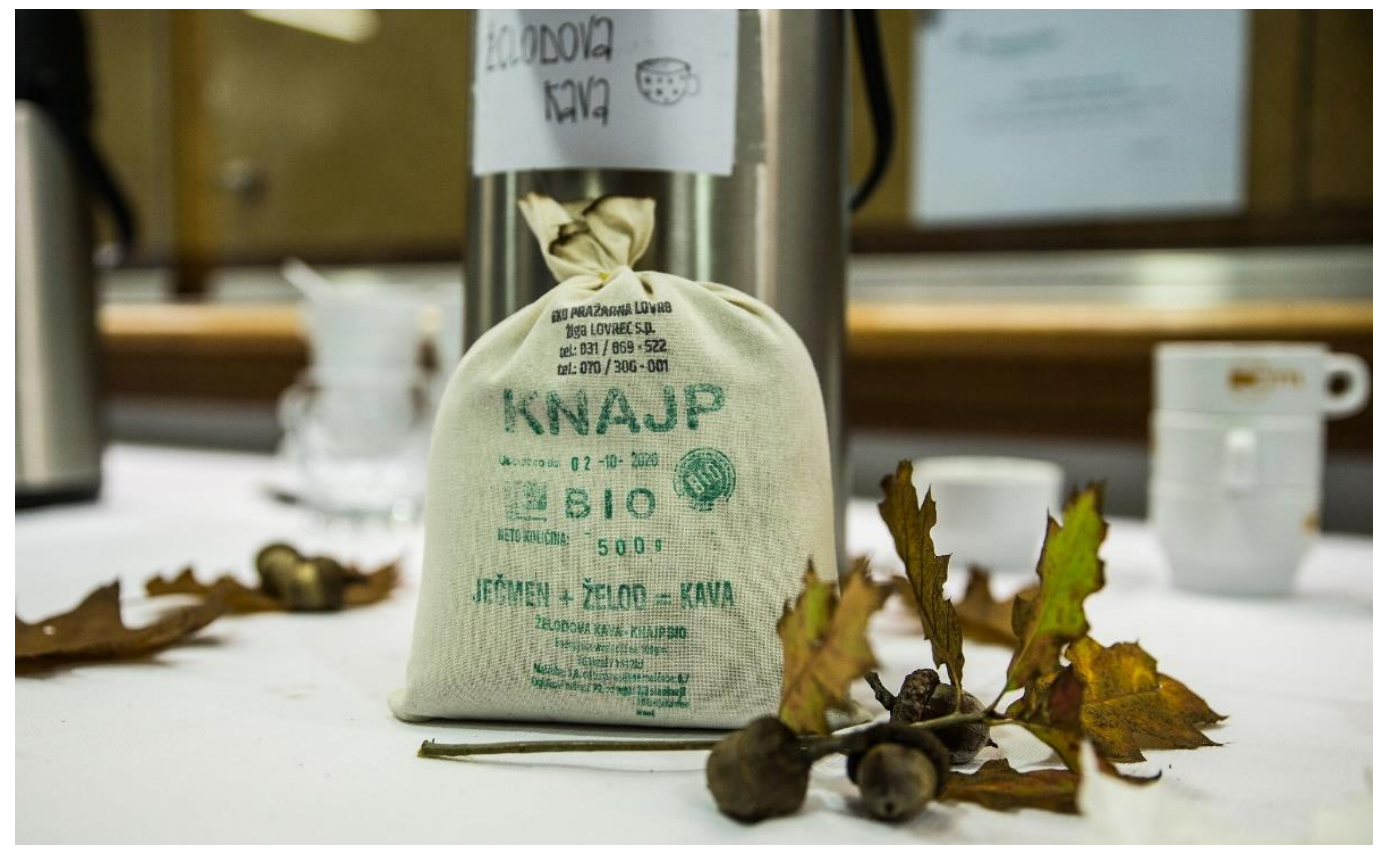

Slika 14: Želodova kava. (foto: G. Skoberne)

Želod je s škrobom bogata hrana, saj ga vsebuje kar eno tretjino. Druge sestavine želoda so sladkorji, ki jih je za desetino vseh suhih snovi, približno enaka je količina čreslovin, zaradi katerih je želod za prehrano brez posebne priprave neuporaben.
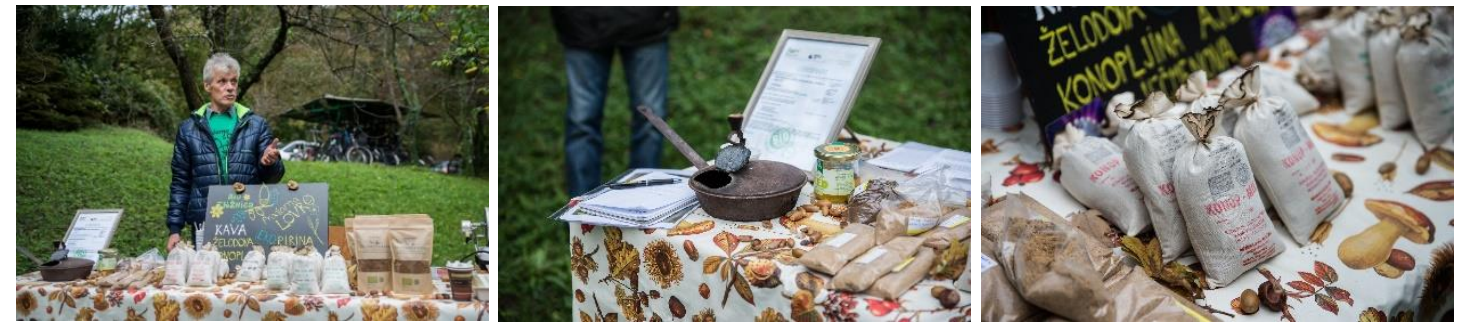

Slika 15: Predstavitev in pokušina želodove kave na zunanjem delu seminarja. (foto: G. Skoberne) 


\section{Preizkusite svoj VONJ}

\section{GOBE ALI GLIVE - KAKO SE PRAV REČE?}

dr. Tine Grebenc, Gozdarski inštitut Slovenije

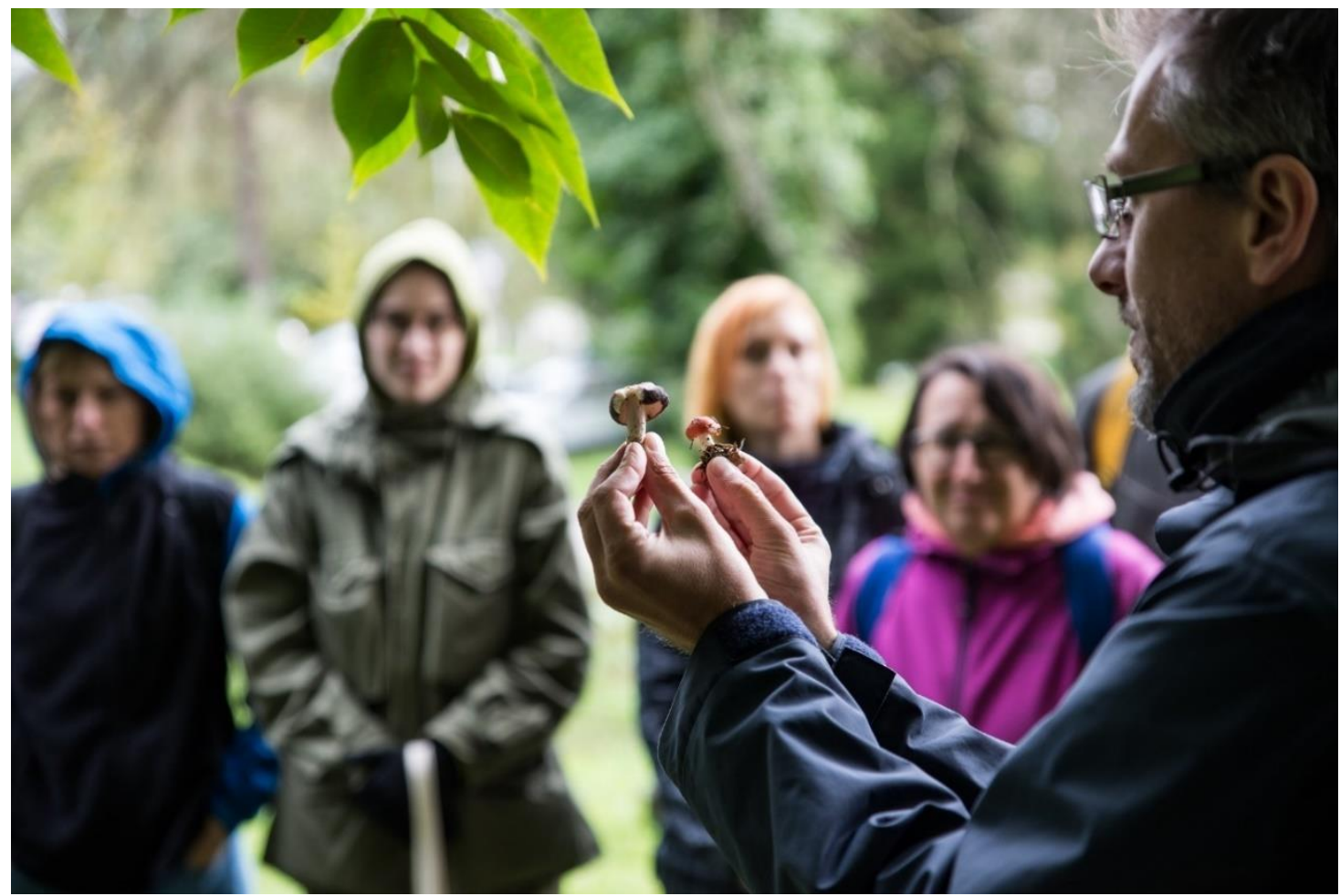

Slika 16: Različne glive - različen vonj. (foto: G. Skoberne)

Glive so zaradi načina prehranjevanja tudi zelo pomembni členi v ekosistemih.
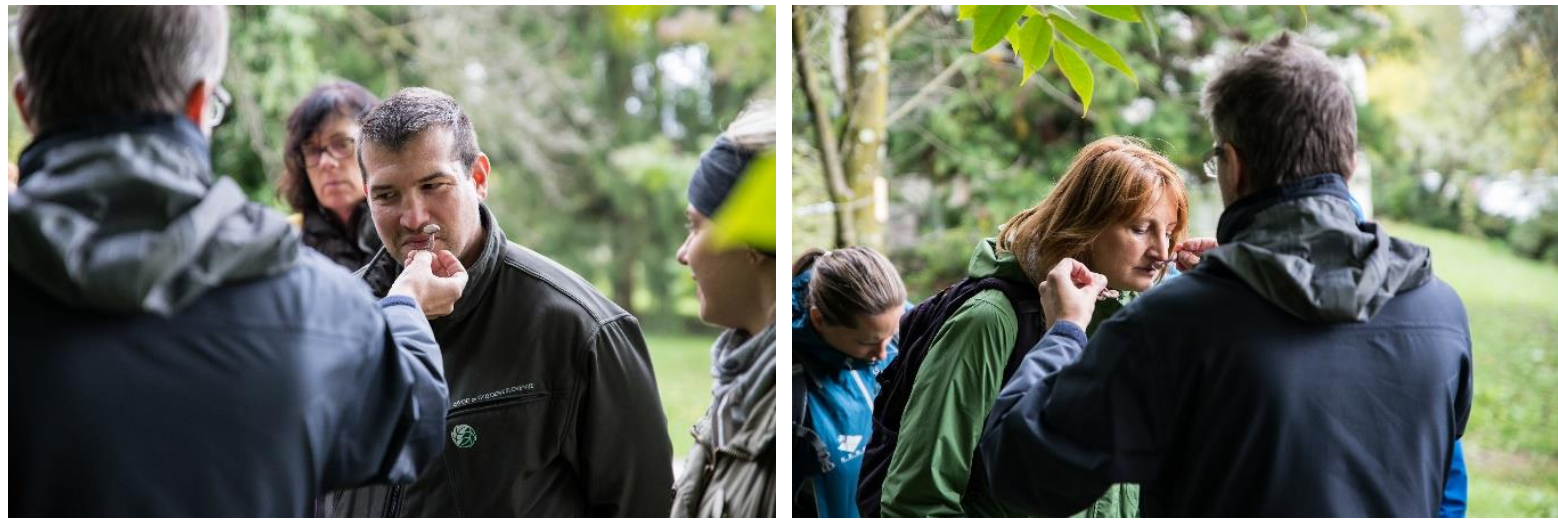

Slika 17: Vonjali smo lahkohlapne organske molekule, ki se med vrstami gliv razlikujejo. (foto G. Skoberne) 


\section{Prehranjevanje gliv}

Glive se prehranjujejo na drugačen način kot rastline. Čeprav so nekatere glive lahko obarvane zeleno, to ni posledica prisotnosti klorofila, ki je značilen za rastline. Ne gre torej za fotosintetsko aktivne glive.

Glive za svoj obstoj nujno potrebujejo organske snovi, ki pa jih za razliko od rastlin niso sposobne proizvesti same, ampak jih pridobijo na različne načine. Različne načine prehranjevanja gliv prikazuje tudi spodnja shema.

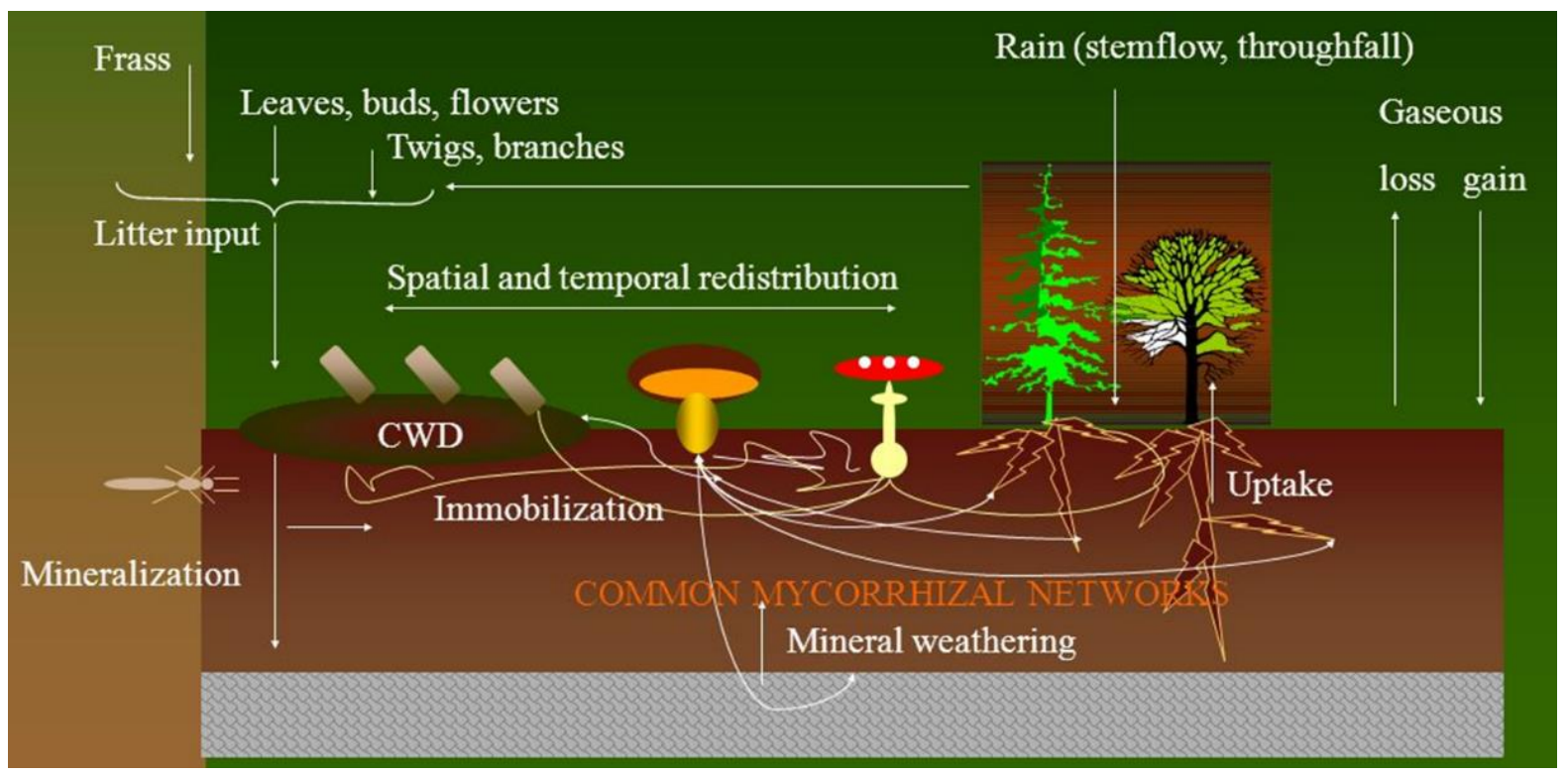

Slika 18: Shema različnih načinov prehranjevanja gliv (Kraigher et al. 2008).

Po načinu prehranjevanja glive delimo na tri skupine:

- gniloživke ali saprofitske glive - te se hranijo z odmrlim ali razpadajočim organskim ostankom (listni opad, cvetovi, veje, mrtve živali, ...),

- soživke ali simbiontske glive - te živijo v sožitju (simbiozi) z drugimi organizmi, rastlinami; sem spadajo tudi mikorizne glive, ki tvorijo sožitje z drevesi,

- zajedalske ali parazitske glive - te hranilne snovi črpajo iz drugih živih organizmov (živali, rastlin). 


\section{Na smreko po ZDRAVJE}

\section{MAZILO IZ SMREKOVE SMOLE}

Matic Konc, Smrekovit

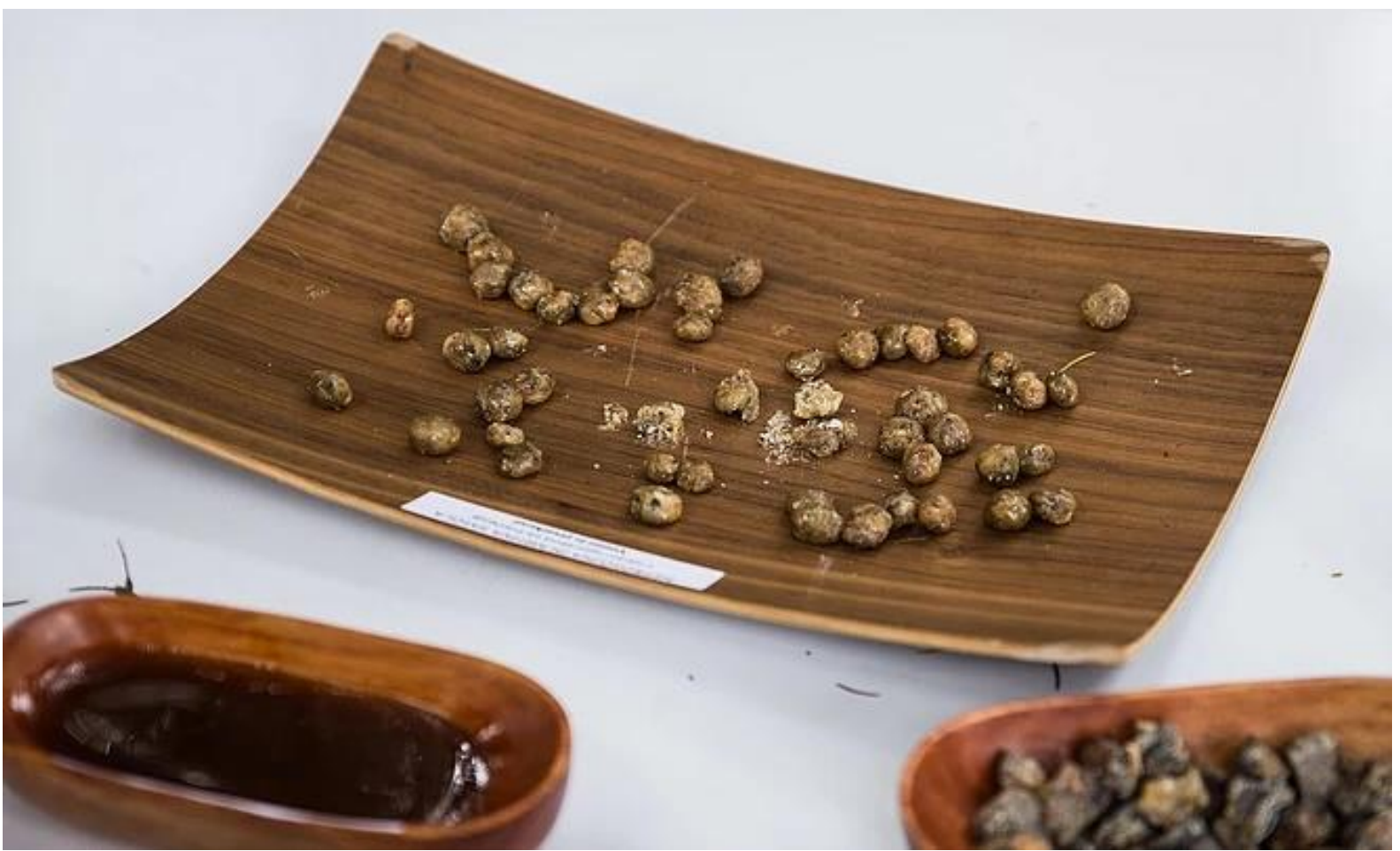

Slika 19: Smrekova smola, ki jo lahko žvečite. (foto: G. Skoberne).

Smrekovo smolo, pa tudi smolo drugih dreves, so uporabljali že $v$ kameni dobi. Finski študenti arheologije so leta 2007 našli košček najstarejšega do zdaj znanega žvečilnega gumija iz smrekove smole, ki ga je skrival iglasti gozd v bližini glavnega mesta Finske. Najdba datira 5000 let pred našim štetjem. Ljudje so si tako z žvečenjem smole lajšali boleče grlo in vnetje dlesni.

Na smreki in boru najdemo smolo $v$ treh oblikah - prosojno in tekočo, prosojno in strjeno ter neprosojno in deloma strjeno. Za žvečenje je primerna slednja, neprosojna in deloma strjena smola.

Po zgledu ameriških Indijancev je John B. Curtis izdelal prvi komercialni žvečilni gumi, ki je bil narejen iz smrekove smole in čebeljega voska.

Indijanci pa smole niso uporabljali le za žvečenje, temveč tudi za zdravljenje drugih težav, kot so rane in bolezni sklepov. Za ta namen je v naravi najbolj uporabna prosojna in tekoča oblika smole. Najlažje jo je najti na boru. Tudi ljudsko zdravilstvo v Sloveniji pozna uporabo surove smole.

$\checkmark$ nordijskem prostoru so izdelovali tradicionalno mazilo z maslom in smrekovo smolo, kar je smoli dalo novo uporabnost, saj je dodatek masla omogočal, da je bil izdelek lepo mazljiv in nelepljiv. Za našo delavnico smo pripravili takšno tradicionalno finsko mazilo z maslom. 


\section{TRADICIONALNO FINSKO SMREKOVO MAZILO}

Za izdelavo mazila potrebujemo prosojno smolo, ki jo najdemo na smrekah in borih. Maslo in smolo nato segrejemo $\mathrm{v}$ čaši nad alkoholnim gorilnikom in ga vlijemo $\mathrm{v}$ posodico, da se strdi. Mazilo je tako pripravljeno za uporabo!

Smrekova smola je sestavljena iz več kot 80 različnih organskih spojin, njen učinek pa najverjetneje izhaja iz sinergizma več snovi, prisotnih v smoli.

Njen natančen mehanizem je znan le pri fungicidnem delovanju na glive, kjer so znanstveniki opazovali njeno delovanje na hife gliv pod elektronskim mikroskopom. Poleg njenega izredno močnega protimikrobnega (proti vsem dermatofitom in proti vsem gram negativnim bakterijam, vključno z MRSO in VRE, kar so dokazali prej omenjeni finski znanstveniki) deluje tudi proti praktično vsem vnetjem, najverjetneje z vplivom na lokalni imunski odziv, čeprav njen tovrstni mehanizem še ni raziskan. Ravno zaradi naštetih lastnosti je tudi izredno močan naravni konzervans.
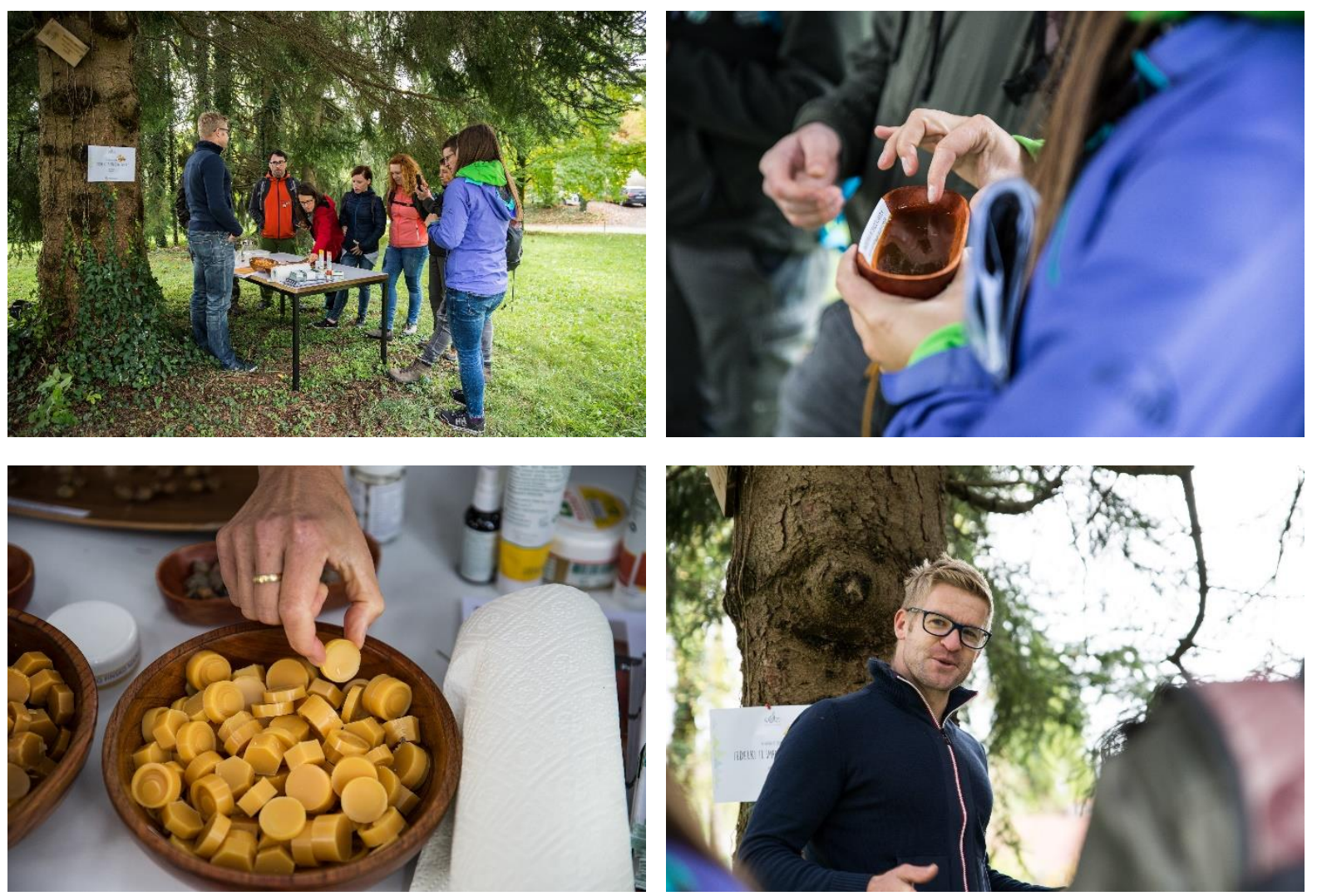

Slika 20: Delavnica okušanja in vonja zdravilnih izdelkov iz smrekove smole. (foto: G. Skoberne) 


\section{Naredite kemijski EKSPERIMENT}

\section{BELA JELKA IN BELINAL}

dr. Samo Kreft, Fakulteta za farmacijo

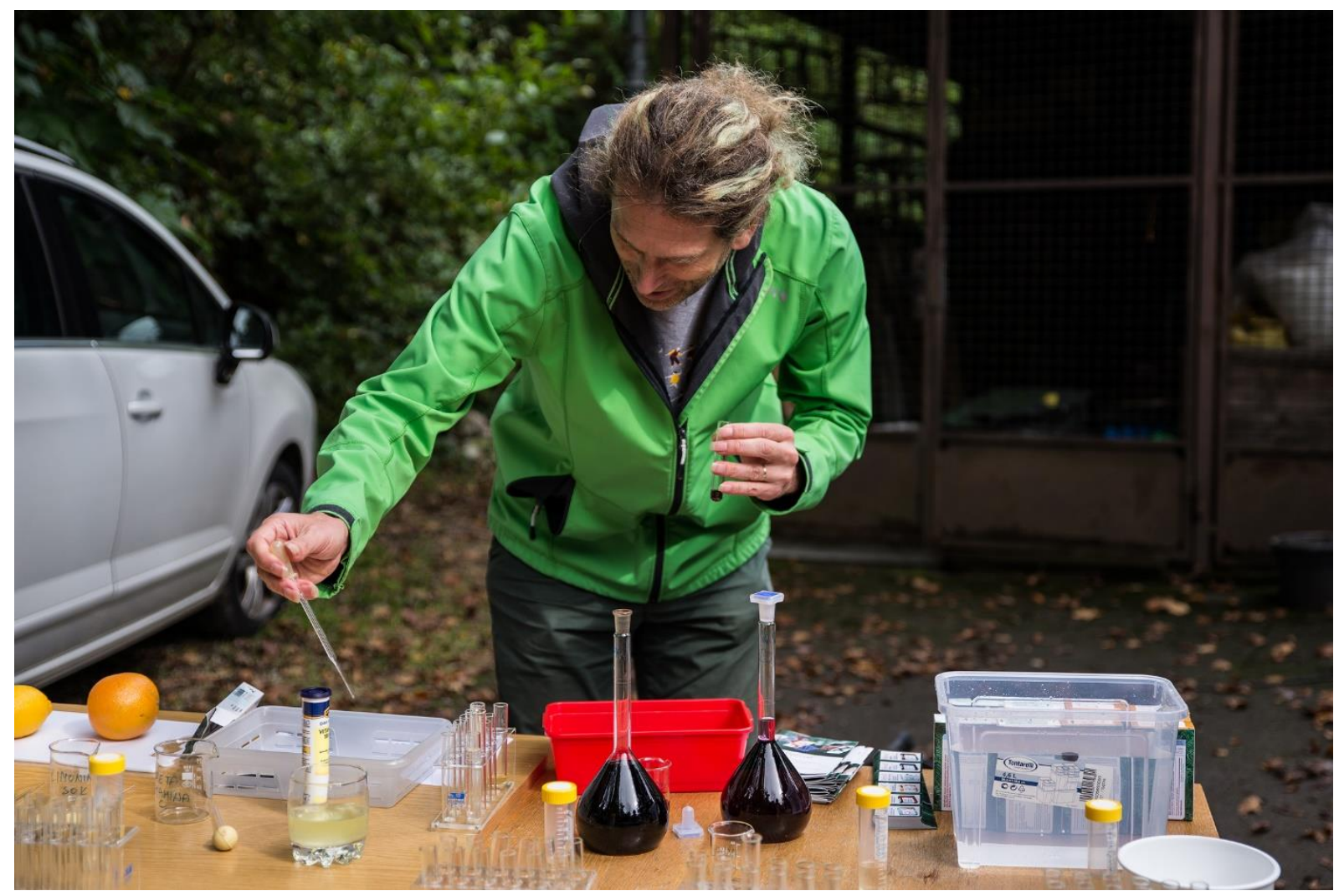

Slika 21: Naredite svoj kemijski eksperiment. (foto: G. Skoberne)

Prosti radikali so reaktivne snovi, ki hote ali nehote nastajajo v našem telesu in povzročajo okvare celic. Antioksidanti pa so snovi, ki lovijo proste radikale in s tem preprečujejo poškodbe celic. Antioksidanti lahko nastajajo v našem telesu, lahko pa jih zaužijemo. V eksperimentu smo preizkušali, kakšna je sposobnost različnih antioksidantov za lovljenje prostih radikalov. 

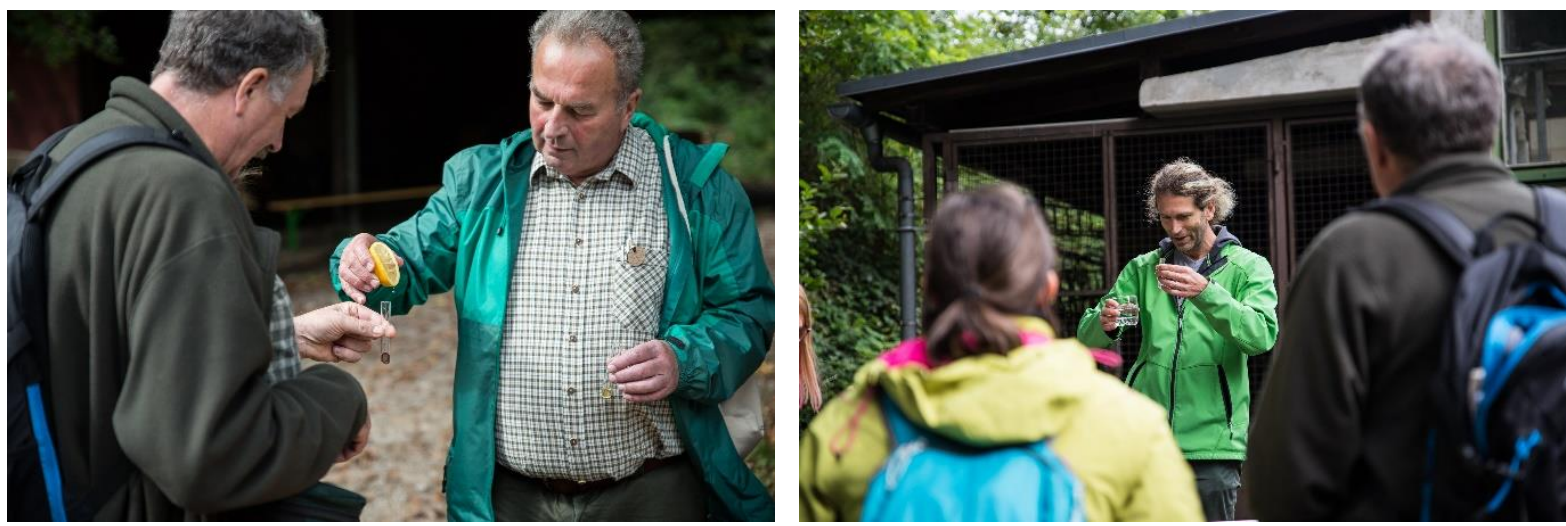

Slika 22: Eksperimentiranje z bazami in kislinami (foto: G. Skoberne)

\section{Potek poskusa in razlaga za udeležence:}

V epruveto smo nalili raztopino prostih radikalov. Zaradi lažjega opazovanja smo uporabili modro obarvane sintezno pridobljene proste radikale, imenovane s kratico DPPH. Ko jim dodamo antioksidant, ta ulovi radikale in jih uniči, zato izgubijo modro barvo. $V$ to epruveto $z$ radikali smo postopoma po kapljicah dodajali čisti sveže iztisnjen limonin sok (nerazredčen), ki vsebuje veliko vitamina C, ki je znan kot dober antioksidant. Šteli smo, koliko kapljic limoninega soka je bilo potrebnih, da je modra barva radikalov povsem izginila. Potrebnih je bilo približno 10 kapljic. Potem lahko to antioksidativno moč limoninega soka primerjamo še $s$ kakšnim drugim vzorcem. V našem primeru smo na delavnici vzeli kapsulo Belinala, jo stresli v epruveto z $10 \mathrm{ml}$ navadne vode in na hitro pomešali. $V$ epruveto z modro raztopino radikalov smo dodajali to mešanico Belinala v vodi. Že po eni kapljici radikali izgubijo vso modro barvo. S tem smo ugotovili, da ima Belinal razredčen $z$ vodo $10 x$ večjo antioksidativno aktivnost (sposobnost lovljenja radikalov) kot čisti limonin sok. Za bolj natančno štetje kapljic bi lahko obe raztopini (limonin sok in Belinal) še dodatno razredčili.

\section{Strokovna razlaga za mentorje:}

Modri radikali v epruveti so $\underline{\mathrm{DPPH}}$, ki so eden najbolj standardnih radikalov za preiskušanje antioksidativne aktivnosti vzorcev. Za ta eksperiment je najboljša raztopina $40 \mathrm{mg} / \mathrm{L} \mathrm{DPPH} \mathrm{v}$ metanolu.

Limonin sok vsebuje približno $50 \mathrm{mg} / 100 \mathrm{ml}$ vitamina C. 


\section{Naštejte svoje ČUTE}

\section{VSEH 5 ČUTIL NAJ SE PREBUDI}

dr. Peter Železnik, Gozdarski inštitut Slovenije

Človeški možgani so do sedmega leta primarno čutni procesor, tj. organ, namenjen za obdelovanje podatkov, ki jih človek prejema preko čutil. Šele z leti pa se pri otrocih povečuje zmožnost abstraktnega razumevanja, zato je v zgodnji mladosti najbolje, da otroci prebivajo čim več časa v okolju, ki vzpodbuja raznolike senzorične izkušnje. Čim bolj so izkušnje kompleksne, tem več povezav se pri tem tvori med nevroni v možganih (Györek in sod. 2014). Gozd s svojo kompleksnostjo je idealno okolje za raznolike čutne izkušnje in s tem poglobljeno doživljanje.

Med senzoričnimi izkušnjami zaradi moderne tehnologije predvsem prevladujejo vidne in slušne, zato se med aktivnostjo raje fokusiramo na vonj in tip.
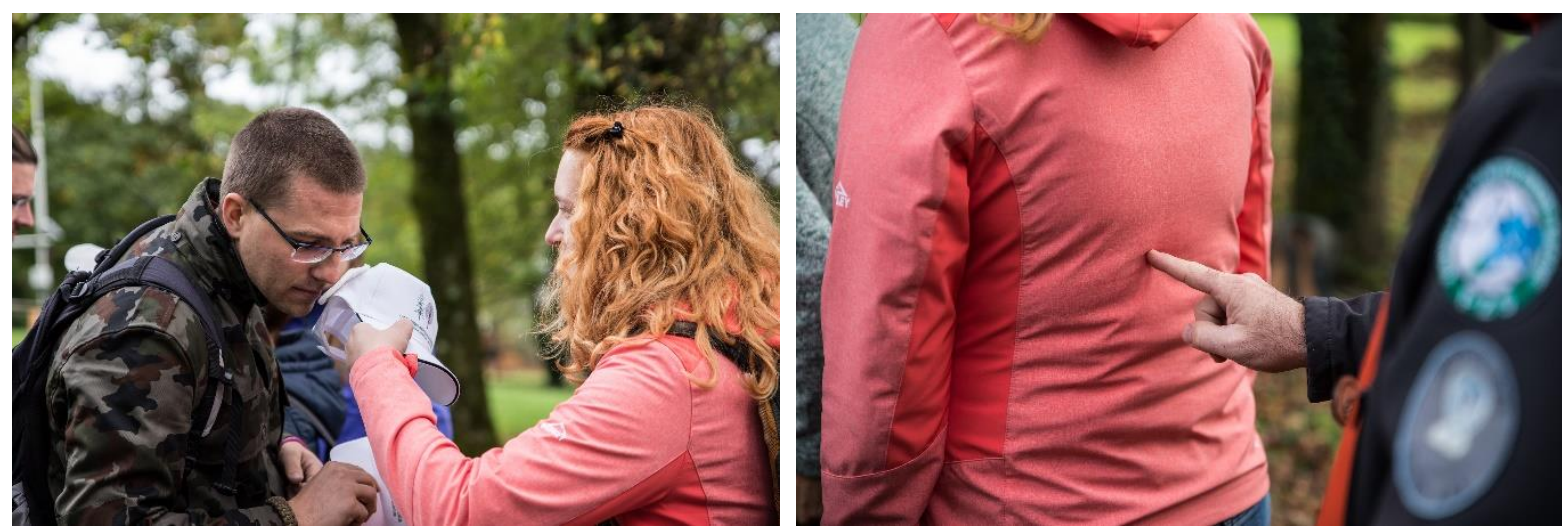

Slika 23: Delavnica senzorične izkušnje: testirali smo voh in čut za dotik. (foto: G. Skoberne)

Število udeležencev: skupine do 7 članov (maksimalno 21 udeležencev)

Čas: $30-45$ minut

Kaj potrebujemo: pripomočke, na katere nanesemo vonjave (kape, vato ipd.)

Izvedba: Na kape s senčnikom smo pripeli koščke vate, na katere smo nakapali različna eterična olja. Pri izbiri vonjev je potrebno paziti, da so čim bolj različni, drugače je razločevanje zelo težko. Eterična olja ali podoben dišeče snovi morajo biti brez barve.

Kape s pripetimi koščki vate so bili razporejeni po podlogi. Vsak si je izbral svojega, nato so se glede na vonje razdelili po skupinah. Po delitvi v skupine se izvede dodatno aktivnost, da se člani posamezne skupine bolj povežejo med seboj.

Nato se skupine razporedilo pred voditeljem $v$ vrste. Prvi v vrsti je gledal voditelja, ostali mu obrnejo hrbet. Voditelj je pokazal sliko, ki jo prvi v skupini s prstom »naslika« naslednjemu na hrbet (debela oblačila so lahko problem). Nato so si člani skupine podajali signal s prstom naprej, zadnji v skupini pa je iz naravnih materialov na tleh sestavil sliko, ki jo je prejel na hrbet. Komunikacijsko verigo smo ponovili večkrat. 


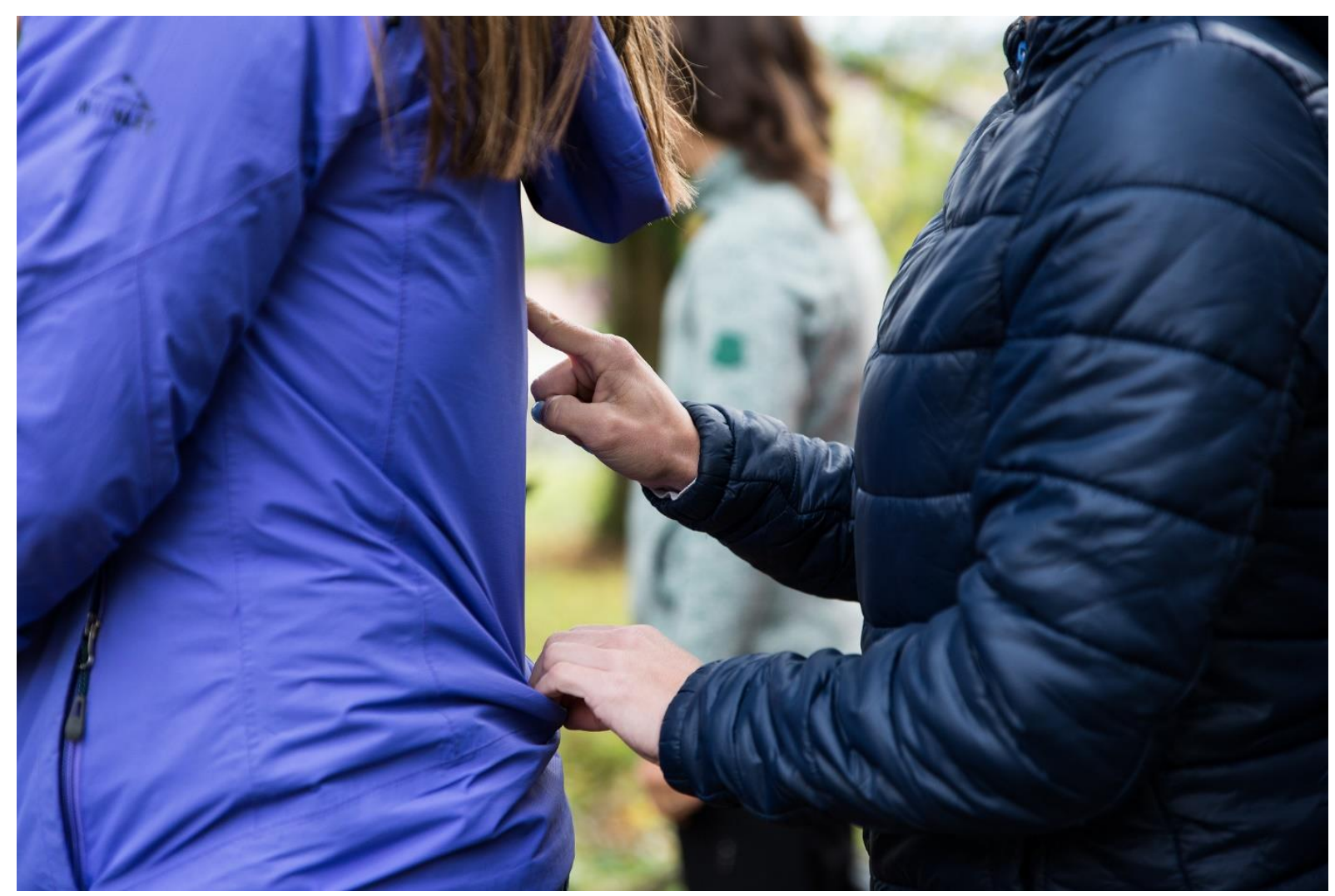

Slika 24: Ali prepoznate narisano obliko? (foto: G. Skoberne).
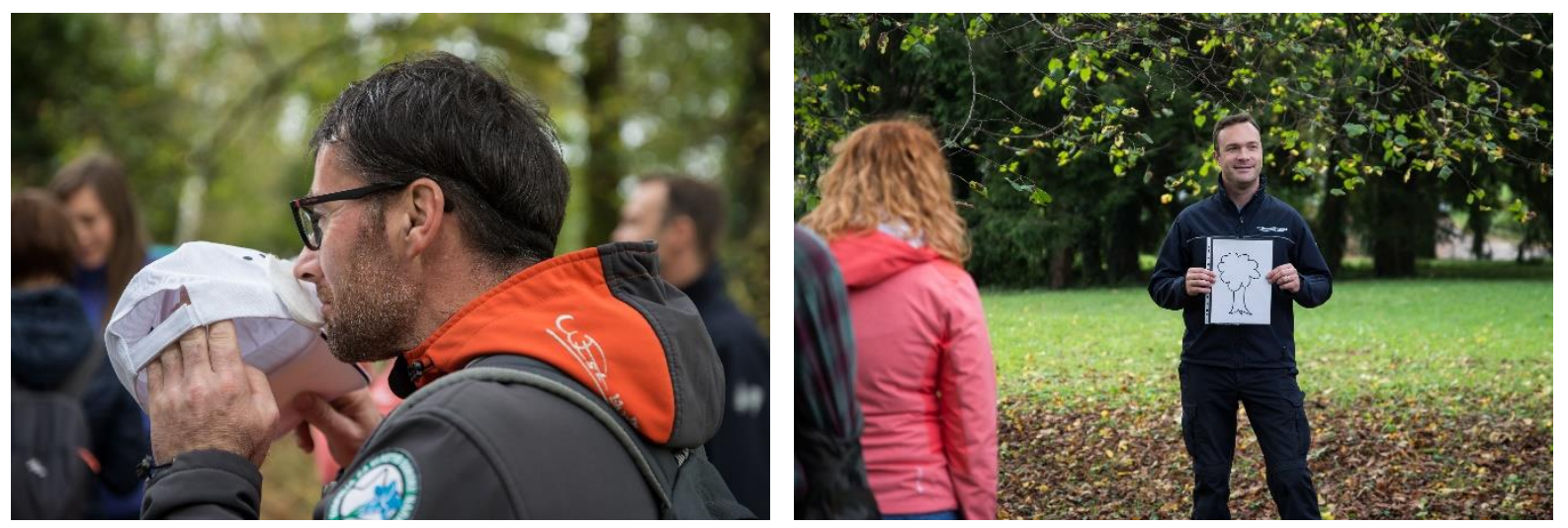

Slika 25: Po čem diši? Kaj so mi narisali na hrbet? (foto: G. Skoberne) 


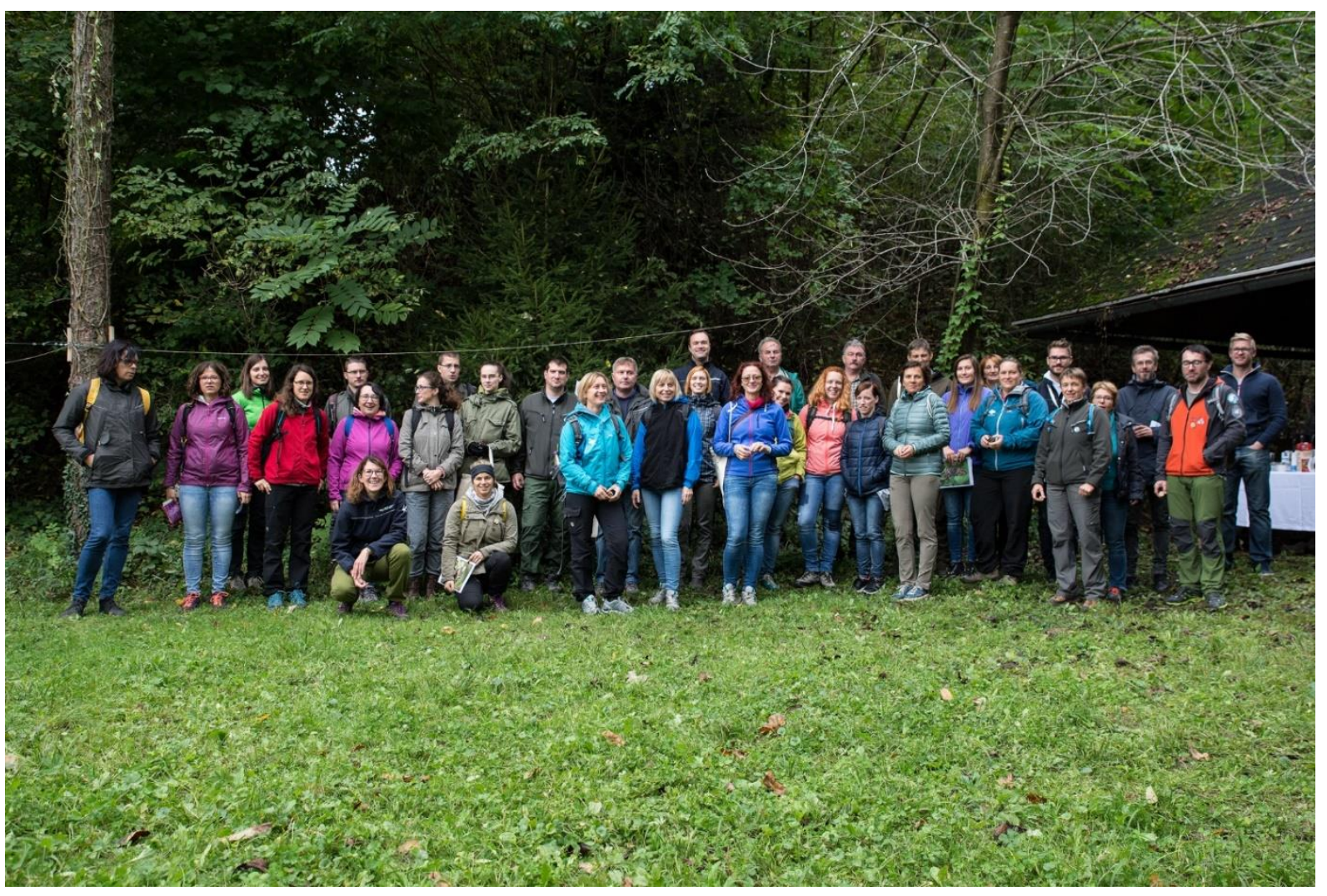

Slika 26: Pestrost udeležencev je prinesla marsikatero novo idejo ali pomislek. (foto: G. Skoberne)

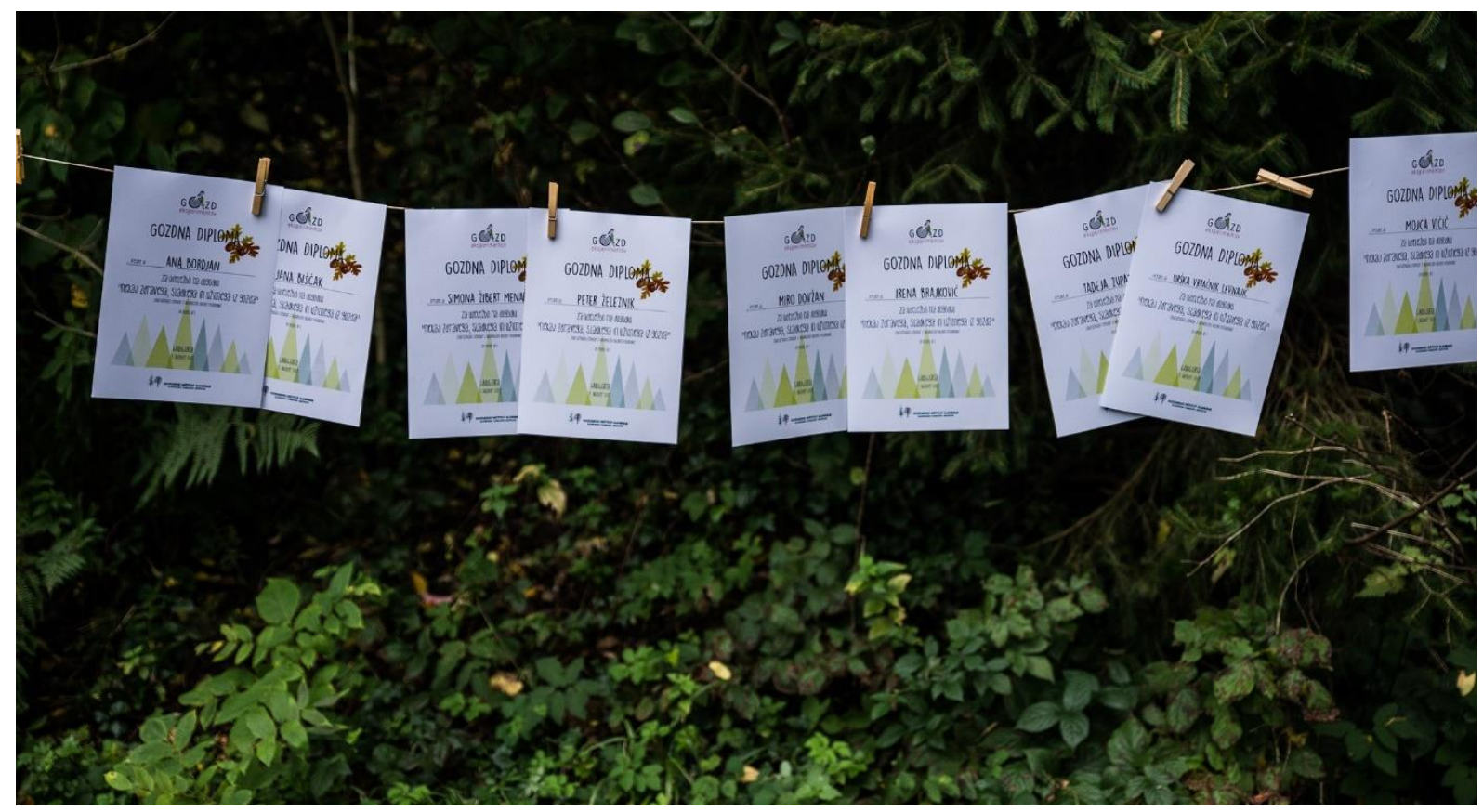

Slika 27: Naj bo tudi iskanje svoje gozdne diplome izziv. (foto: G. Skoberne) 


\section{VIRI}

Debeljak, J.; Ferk, P.; Čokolič, M.; Zavratnik, A.; Tavč Benković, E.; Kreft, S.; Štrukelj, B. Randomised, double blind, cross-over, placebo and active controlled human pharmacodynamic study on the influence of silver fir wood extract (Belinal) on post-prandial glycemic response. Die Pharmazie 2016 (71) 566-569.

Drevenšek G, Lunder M, Benković ET, Mikelj A, Štrukelj B, Kreft S. Silver fir (Abies alba) trunk extract protects guinea pig arteries from impaired functional responses and morphology due to an atherogenic diet. Phytomedicine. 2015;22(9):856-61.

Drevenšek G, Lunder M, Benković ET, Štrukelj B, Kreft S. Cardioprotective effects of silver fir (Abies alba) extract in ischemic-reperfused isolated rat hearts. Food Nutr Res. 2016. ;60:29623.

E. Tavčar Benković, D. Žigon, V. Mihailović, T. Petelinc, P. Jamnik \& S. Kreft (2017) Identification, in vitro and in vivo antioxidant activity, and gastrointestinal stability of lignans from silver fir (Abies alba) wood extract, J. of Wood Chemistry and Technology.

Györek in sod. 2014. Otroci potrebujemo gozd : (gozdna popotnica). Kamnik : Vrtec Antona Medveda : Inštitut za gozdno pedagogiko. https://plus.cobiss.si/opac7/bib/274744064

Tavčar N. 2016. S placebom kontrolirana študija vpliva kreme z ekstraktom lesa bele jelke (Abies alba Mill.) na kožo, Magistrsko delo.

Vilhar in sod. 2019. Priročnik za učenje in igro v gozdu. Ljubljana : Gozdarski inštitut Slovenije, Založba Silva Slovenica.

Prešern J. 2019. Beseda leta je bila ? : predavanje na jesenskem izobraževalnem seminarju z aktivnostmi gozdne pedagogike "Nekaj Zdravega, sladkega in užitnega iz gozda", Gozdarski inštitut Slovenije, Ljubljana, 3. 10. 2019

Japelj, A., Planinšek, Š. 2019. Slovenci = nabiralci : predavanje na jesenskem izobraževalnem seminarju z aktivnostmi gozdne pedagogike "Nekaj zdravega, sladkega in užitnega iz gozda", Gozdarski inštitut Slovenije, Ljubljana, 3. 10. 2019.

Kreft S. 2019. Lekarna brez gozda ne obstaja: predavanje na jesenskem izobraževalnem seminarju z aktivnostmi gozdne pedagogike "Nekaj zdravega, sladkega in užitnega iz gozda", Gozdarski inštitut Slovenije, Ljubljana, 3. 10. 2019.

Kreft S. 2019. Naredite kemijski eksperiment : delavnica na jesenskem izobraževalnem seminarju z aktivnostmi gozdne pedagogike "Nekaj zdravega, sladkega in užitnega iz gozda", Gozdarski inštitut Slovenije, Ljubljana, 3.10.2019.

Grebenc T. 2019. Gobe ali glive - kaj se prav reče? : predavanje na jesenskem izobraževalnem seminarju z aktivnostmi gozdne pedagogike "Nekaj zdravega, sladkega in užitnega iz gozda", Gozdarski inštitut Slovenije, Ljubljana, 3.10.2019.

Grebenc T. 2019. Preizkusite svoj vonj : delavnica na jesenskem izobraževalnem seminarju z aktivnostmi gozdne pedagogike "Nekaj zdravega, sladkega in užitnega iz gozda", Gozdarski inštitut Slovenije, Ljubljana, 3.10.2019.

Železnik P. 2019. Naštejte svoje čute : delavnica na jesenskem izobraževalnem seminarju z aktivnostmi gozdne pedagogike "Nekaj zdravega, sladkega in užitnega iz gozda", Gozdarski inštitut Slovenije, Ljubljana, 3.10.2019. 